\title{
Inorganic Chemistry
}

\section{Pyriplatin-Boron-Dipyrromethene Conjugates for Imaging and Mitochondria-Targeted Photodynamic Therapy}

\author{
Md Kausar Raza, ${ }^{\dagger}$ Srishti Gautam, ${ }^{\ddagger}$ Prodip Howlader, ${ }^{\dagger}$ (®) Arnab Bhattacharyya, ${ }^{\dagger}$ Paturu Kondaiah, ${ }^{*}{ }^{\ddagger}$ \\ and Akhil R. Chakravarty*, ${ }^{*}$
} $\dagger$ Department of Inorganic and Physical Chemistry and ${ }^{\dagger}$ Department of Molecular Reproduction Development and Genetics, Indian
Institute of Science, Bangalore 560012, India

Supporting Information

ABSTRACT: Monofunctional pyriplatin analogues cis-[Pt$\left.\left(\mathrm{NH}_{3}\right)_{2}(\mathrm{~L}) \mathrm{Cl}\right]\left(\mathrm{NO}_{3}\right)$ (1-3) having boron-dipyrromethene (BODIPY) pendants (L) with 1,3,5,7-tetramethyl-8-(4-pyridyl)-4,4'-difluoroboradiazaindacene moieties were designed and synthesized, and their photocytotoxic properties were studied. The Pt-BODIPY conjugates displayed an absorption band within $505-550 \mathrm{~nm}$ and a green emissive band near $535 \mathrm{~nm}$ in $1 \%$ DMSO/DMEM (Dulbecco's modified Eagle's medium) buffer. Complex cis- $\left[\mathrm{Pt}\left(\mathrm{NH}_{3}\right)_{2}(4-\mathrm{Me}-\mathrm{py}) \mathrm{Cl}\right]\left(\mathrm{NO}_{3}\right)$ (4) was used as a control for determining the structural aspects by $\mathrm{X}$-ray crystallography. The mono- and diiodinated BODIPY complexes $\mathbf{2}$ and $\mathbf{3}$ showed generation of singlet oxygen on light

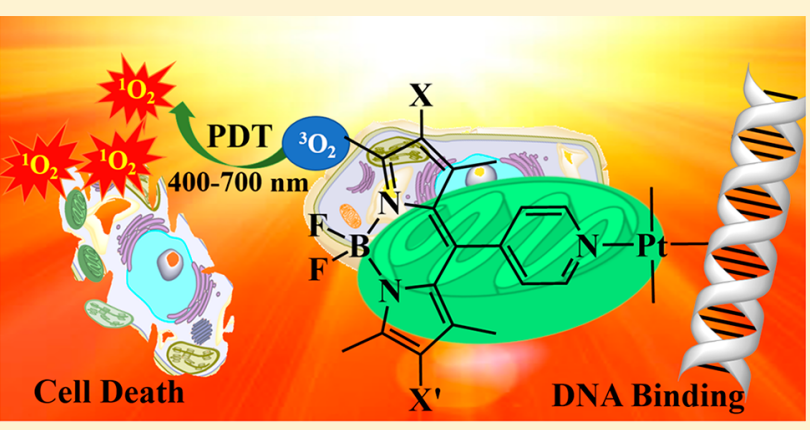
activation as evidenced from the 1,3-diphenylisobenzofuran (DPBF) titration experiments. The cytotoxicity of the BODIPY complexes was tested against A549 (human lung cancer), MCF-7 (human breast cancer), and HaCaT (human skin keratinocyte) cells in dark and visible light $\left(400-700 \mathrm{~nm}, 10 \mathrm{~J} \mathrm{~cm}{ }^{-2}\right)$. While complexes 2 and 3 showed excellent photocytotoxicity $\left(\mathrm{IC}_{50} \approx 0.05 \mu \mathrm{M}\right)$, they remained essentially nontoxic in the dark $\left(\mathrm{IC}_{50}>100 \mu \mathrm{M}\right)$. The emissive bands of 1 and 2 were used for cellular imaging by confocal microscopy study, which showed their mitochondrial localization. This was further supported by platinum estimation from isolated mitochondria and mitochondrial depolarization through a JC-1 assay. The photomediated apoptotic cell death was evidenced from flow cytometric assays, annexin-V/FITC-PI (fluorescein isothiocyanate-propidium iodide) and cell cycle arrest in sub-G1 and G2/M phases. The complexes bind to 9-ethylguanine as a model nucleobase to form monoadducts. A mechanistic study on DNA photocleavage activity using pUC19 DNA showed singlet oxygen as the reactive oxygen species (ROS). The combination of photodynamic therapy with DNA cross-linking property enhanced the anticancer potential of the monofunctional BODIPY-conjugates of pyriplatins.

\section{INTRODUCTION}

Cisplatin and its analogues, namely, oxaliplatin and carboplatin, are the currently used platinum-based chemotherapeutic drugs. $^{1-3}$ The efficacy of such bifunctional anticancer drugs is largely dependent on the rate of hydrolysis of the $\mathrm{Pt}-\mathrm{Cl}$ or $\mathrm{Pt}-\mathrm{O}$ bonds in the intracellular medium besides their cellular uptake properties. The ancillary ammine/amine ligand(s) play important roles in the bond dissociation kinetics. These platinum(II) drugs characteristically form intra- and/or interstrand DNA cross-links with nuclear DNA through covalent bonding at $\mathrm{N} 7$ positions of two guanosine residues and cause a variety of cellular responses including transcription inhibition and cell apoptosis. Despite the clinical success of these bifunctional drugs, they suffer from dose limiting and other side effects. To circumvent the inadequacies of such drug molecules, the chemistry of monofunctional platinum(II) complexes showing antineoplastic activities has received current interest (Figure 1). ${ }^{4-8}$ Lippard and co-workers have developed a series of monocationic platinum(II) complexes including pyriplatin, imidazoplatin, and phenanthriplatin and tested their activity against several tumor cells. ${ }^{2,4,5,7 a}$ Phenanthriplatin and pyriplatin have showed excellent cellular accumulation compared to cisplatin and oxaliplatin, thus having potential for tumor targeting. Although the transcription inhibition of the pyriplatin adducts are similar to that of cisplatin, their reduced efficacy is likely due to the nucleotide excision repair (NER) mechanism being functioning for nuclear DNA. ${ }^{9}$ The NER machinery can be circumvented by directing the complexes toward other cellular organelles such as mitochondria $(\mathrm{mt})$ as the NER process is absent for mtDNA. ${ }^{10}$

Mitochondria being a regulator of the metabolic functions, targeting mitochondria for anticancer activity is a potential alternative strategy. Different types of nanoparticles, metalchromophore, or organic dyes, namely, macrocyclic dyes like porphyrins that include the photodynamic therapy (PDT)

Received: September 7, 2018

Published: October 30, 2018 


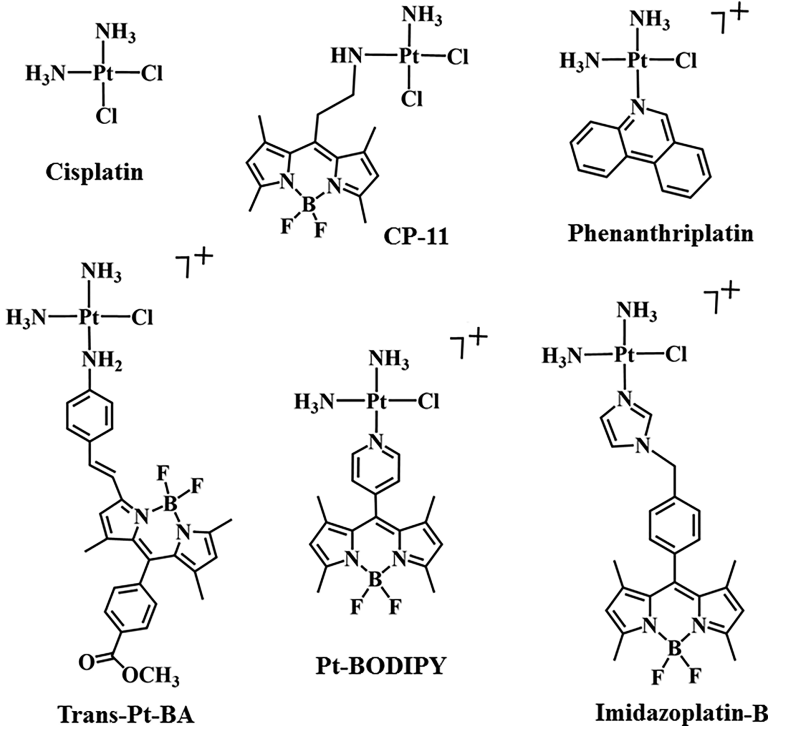

Figure 1. Bifunctional platinum(II) complexes: cisplatin and CP11. ${ }^{1,20 a}$ Monofunctional platinum(II) complexes: phenanthriplatin, ${ }^{5 \mathrm{~b}}$ trans-Pt-BA, ${ }^{8 \mathrm{a}} \mathrm{Pt}-\mathrm{BODIPY},{ }^{22 \mathrm{a}}$ and imidazoplatin-B. ${ }^{8 \mathrm{~b}}$

drug photofrin, and phthalocyanines, are developed to achieve this objective. ${ }^{11-14}$

Boron-dipyrromethene (BODIPY) dyes are known to display localization in different cellular organelles, and the commercially available BODIPY dyes have been extensively used as trackers in cellular imaging studies. ${ }^{15-17}$ The photophysical and photochemical properties make them suitable for bioimaging and as therapeutic agents. Introducing a heavy atom (for example $\mathrm{Br}$ or I) on the BODIPY core increases its efficacy for singlet oxygen $\left({ }^{1} \mathrm{O}_{2}\right)$ generation with a high quantum yield and makes such BODIPY dyes as excellent photosensitizers for in vitro and in vivo photodynamic applications. ${ }^{18}$ Recent reports have shown that BODIPYappended transition metal complexes are useful for real-time drug tracking inside the cells. ${ }^{19-23}$ Recently Guo and coworkers have shown that the monofunctional Pt-BODIPY conjugates sensitize the antitumor activity with the enhancement in the cellular accumulation on short photoirradiation time compared to cisplatin. ${ }^{8 a} \mathrm{Xie}$ and co-workers have demonstrated BODIPY-Pt conjugates as potential candidates for mitochondria targeted cytotoxicity with visualization of platinum distribution in the living cells. ${ }^{21}$ Furthermore, they confirmed from the in vitro and in vivo studies that simultaneously keeping with the fluorescent imaging properties, significant photocytotoxicity can be achieved even at a low concentration of the BODIPY-Pt complex in near-infrared region (NIR). ${ }^{21 b}$ However, the complex exhibited undesirable dark cytotoxicity along with its PDT activity. Although PDT activity of macrocyclic organic dyes, namely, photofrin as hematoporphyrin species and its derivatives, has been investigated in detail, a similar study using platinum(II)BODIPY conjugates remains virtually unexplored. ${ }^{22-25}$

We have recently reported imidazoplatin-BODIPY conjugates as mitochondria-localizing photosensitizers. ${ }^{8 \mathrm{~b}}$ DNA interaction studies have shown that the metal covalently binds to the plasmid pUC19 DNA, and in addition to their cellular PDT activity, the complexes show transcription inhibition property, possibly binding to the mt-DNA. Despite showing excellent photocytotoxic properties, the emissive imidazopla-
tin-B localized in different cellular organelles, namely, the mitochondria $(\mathrm{PCC} \approx 0.7)$ and endoplasmic reticulum (ER), while the diiodo-imidazoplatin-B was used as a PDT agent. ${ }^{8 \mathrm{~b}}$ Among different series of monofunctional platinum(ii) compounds, pyriplatin was extensively studied due to its unique features in comparison to other cisplatin analogues. Pyriplatin was found to have higher anticancer activity in comparison to imidazoplatin as it forms the $\mathrm{Pt}$ adducts to impede the RNA II polymerase activity. ${ }^{2,4,5,7 a}$ In continuation of our current efforts to develop the PDT chemistry of monofunctional platinum(II)-BODIPY conjugates, herein, we have designed a series of BODIPY-conjugated pyriplatin complexes, and the results are compared to that of the reported imidazoplatin-B analogues. ${ }^{8 b, c}$ Herein, we present the synthesis, characterization, and photoinduced anticancer activity of a series of BODIPY-conjugated pyriplatin analogues, namely, cis- $\left[\mathrm{Pt}\left(\mathrm{NH}_{3}\right)_{2}(\mathrm{~L}) \mathrm{Cl}\right]\left(\mathrm{NO}_{3}\right)(\mathbf{1}-\mathbf{3})$, where $\mathrm{L}$ is pyridyl moiety conjugated to 1,3,5,7-tetramethyl-8-(4-pyridyl)-4,4' difluoroboradiazaindacene (BODIPY) $\left(\mathrm{L}^{1}\right.$ in $\left.\mathbf{1}\right)$, monoiodoBODIPY $\left(\mathrm{L}^{2}\right.$ in 2$)$ and diiodo-BODIPY $\left(\mathrm{L}^{3}\right.$ in 3$)$ (Scheme 1$)$.

Scheme 1. Synthetic Pathways Involved and the Chemical Structures of the Ligands $\mathrm{L}^{1}-\mathrm{L}^{3}$ and Their Platinum(II) Complexes 1-3: (i), $\mathrm{HI} / \mathrm{HIO}_{3}$ in Ethanol; (ii), cis$\left[\mathrm{Pt}\left(\mathrm{NH}_{3}\right)_{2} \mathrm{Cl}_{2}\right]+\mathrm{AgNO}_{3}$ in DMF

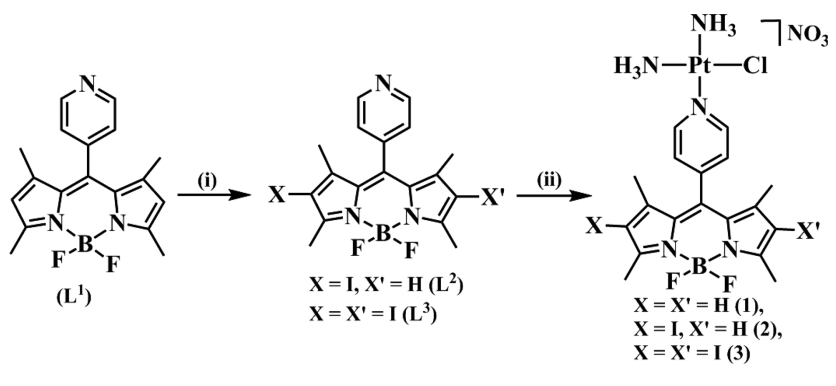

The iodinated BODIPY moieties to different extents is to achieve both tracking by imaging and the PDT effect simultaneously, particularly for complex 2 having a monoiodo-BODIPY unit. Complex 4 of formulation cis-[Pt$\left.\left(\mathrm{NH}_{3}\right)_{2}(\mathrm{~L}) \mathrm{Cl}\right]\left(\mathrm{NO}_{3}\right)$ (4) with $\mathrm{L}$ as 4-methylpyridine (4$\mathrm{MePy}$ ) was prepared, structurally characterized by X-ray crystallography, and used as a control species. Involvement of singlet oxygen as the reactive oxygen species (ROS) is an essential requirement of PDT, and its generation by the complexes 1-3 was studied by titration experiments using 1,3diphenylisobenzofuran (DPBF) as a ${ }^{1} \mathrm{O}_{2}$ quencher and from other cellular experiments. Complex 1 with a highly emissive noniodo BODIPY ligand is designed for cellular imaging, while the nonemissive complex 3 with a diiodo-BODIPY moiety is primarily designed as a photosensitizer to achieve high PDT activity in visible light. Complex 2 with a monoiodinated BODIPY unit is designed for dual activity, namely, for cellular imaging and PDT activity with a moderate effect.

The highlights of this work are (i) visible light-induced PDT activity of the complexes in the cancer cells by singlet oxygen as the ROS with nanomolar $\mathrm{IC}_{50}$ values under light, while being less toxic when kept in the dark, (ii) observation of predominant mitochondrial localization as evidenced from the high Pearson's coefficient value, (iii) potential of DNA crosslink formation using 9-ethylguanine as a model nucleobase in noncellular experiments, and (iv) apoptotic cell death caused by the ROS. This work exemplifies monofunctional platinum- 
(II) complexes, classified as "pyriplatin-B", with the complexes showing their utility in photochemotherapy as a combination of PDT and chemotherapy toward enhancing the therapeutic potential of an anticancer agent.

\section{EXPERIMENTAL SECTION}

Materials and Instruments. The chemicals were purchased and used for reactions without further purification. Elemental analytical data $(\mathrm{CHN})$ were obtained from the IISc analytical service facility using Thermo Finnigan FLASH EA 1112 equipment. The NMR and mass spectral data were obtained using a Bruker Avance NMR spectrometer and Agilent 6538 Ultra High Definition (UHD) Accurate Mass-Q-TOF (LC-HRMS) instrument. The electronic spectral studies were performed using PerkinElmer Spectrum 750 spectrophotometer and HORIBA Jobin Yvon IBH TCSPC fluorimeter (fitted with FluoroHub software analysis). The photocytotoxicity studies were conducted using a Luzchem photoreactor (model LZC-1, Ontario, Canada) fitted with eight fluorescent Sylvania white tubes $(\lambda=400-700 \mathrm{~nm})$. The flow cytometric experiments were carried out using an FACS Verse instrument (BD Biosciences) fitted with a MoFLo XDP cell sorter and with three lasers $(\lambda=488,365$, and $640 \mathrm{~nm})$ containing 10 -color parameters.

Synthesis. Synthetic steps involved in the formation of the BODIPY ligands and their respective complexes are given in Scheme 1. Ligands $\mathrm{L}^{1}, \mathrm{~L}^{3}$, and the complexes $\mathbf{1}$ and $\mathbf{4}$ were prepared according to modified literature procedures. ${ }^{5,8 b, 21 a, 26}$ The characterization data of the ligands are given as Supporting Information.

Synthesis of cis- $\left[\mathrm{Pt}\left(\mathrm{NH}_{3}\right)_{2}(\mathrm{~L}) \mathrm{Cl}\right]\left(\mathrm{NO}_{3}\right)(1-4)$. Cisplatin $(150 \mathrm{mg}$, $0.5 \mathrm{mmol}$ ) was first dissolved in $5 \mathrm{~mL} \mathrm{~N}, \mathrm{~N}$-dimethylformamide (DMF) followed by addition of $\mathrm{AgNO}_{3}(76 \mathrm{mg}, 0.45 \mathrm{mmol}, 0.9$ equiv) to the solution. The reaction mixture was protected from light and stirred at room temperature for $24 \mathrm{~h}$. The precipitated silver chloride was removed by filtration, and the ligand (146 mg L ${ }^{1}, 203 \mathrm{mg}$ $\mathrm{L}^{2}, 260 \mathrm{mg} \mathrm{L}^{3}$ and $42 \mathrm{mg} \mathrm{L}^{4}$ (0.45 mmol, 0.9 equiv)) was added to the solution. The reaction mixture was further stirred for another $24 \mathrm{~h}$ at room temperature. The solvent was removed by using rotary evaporator, and the residue was redissolved in $40 \mathrm{~mL}$ of methanol. The unreacted yellow colored cisplatin was separated by filtration. Diethyl ether $(60 \mathrm{~mL})$ was added into the filtrate under vigorous stirring condition to obtain the product as a solid precipitate. The desired product was obtained, treated twice with $50 \mathrm{~mL}$ of diethyl ether before vacuum drying, and kept in the dark protected from light. cis- $\left[\mathrm{Pt}\left(\mathrm{NH}_{3}\right)_{2}\left(\mathrm{~L}^{1}\right) \mathrm{Cl}\right]\left(\mathrm{NO}_{3}\right)(1) .{ }^{21 a}$ Greenish-red solid. Yield: $200 \mathrm{mg}$ $(70 \%, 0.3 \mathrm{mmol})$. Anal. Calcd for $\mathrm{C}_{18} \mathrm{H}_{24} \mathrm{BClF}_{2} \mathrm{~N}_{6} \mathrm{O}_{3} \mathrm{Pt}\left(M_{\mathrm{w}}\right.$ : 651.7698): C, 33.17; H, 3.71; N, 12.89. Found: C, 32.85; H, 3.73; $\mathrm{N}$, 12.67. HRMS $m / z$ : Calcd for $\left[\mathrm{M}-\mathrm{NO}_{3}\right]^{+}, 589.1429$; Found: 589.1429. ${ }^{1} \mathrm{H}$ NMR $\left(400 \mathrm{MHz}\right.$, DMSO- $\left.d_{6}\right): \delta 8.91(\mathrm{~d}, J=6.11 \mathrm{~Hz}$, $2 \mathrm{H}), 7.76(\mathrm{~d}, J=8.03 \mathrm{~Hz}, 2 \mathrm{H}), 6.25(\mathrm{~s}, 2 \mathrm{H}), 4.75(\mathrm{~s}, 3 \mathrm{H}), 4.37(\mathrm{~s}$, $3 \mathrm{H}), 2.46(\mathrm{~s}, 6 \mathrm{H}), 1.40(\mathrm{~s}, 6 \mathrm{H})$ (s, singlet; d, doublet). ${ }^{13} \mathrm{C}$ NMR $\left(100 \mathrm{MHz}, \mathrm{DMSO}-d_{6}\right): \delta 157.12,154.64,151.48,143.43,130.16$, 126.92, 124.11, 123.04, 15.44, 15.20, 15.03 ppm. ${ }^{11} \mathrm{~B}$ NMR (100 $\left.\mathrm{MHz}, \mathrm{DMSO}-d_{6}\right): 0.54(\mathrm{t}, 1 \mathrm{~B})\left(\mathrm{t}\right.$, triplet). ${ }^{19} \mathrm{~F}$ NMR $(100 \mathrm{MHz}$, DMSO- $d_{6}$ ): -143.59 (quartet, $2 \mathrm{~F}$ ). UV-visible (1\% DMSO/DMEM at $\mathrm{pH} 7.2): \lambda_{\max } \mathrm{nm}\left(\varepsilon, \mathrm{M}^{-1} \mathrm{~cm}^{-1}\right)=505(41100), 475(11790$, shoulder), 371 (4045). Emission (1\% DMSO/DPBS at pH 7.2): $\lambda_{\mathrm{em}}$ $\left(\lambda_{\mathrm{ex}}, \Phi_{\mathrm{F}}\right)=530 \mathrm{~nm}(490 \mathrm{~nm}, 0.07)$.

cis-[Pt $\left.\left(\mathrm{NH}_{3}\right)_{2}\left(\mathrm{~L}^{2}\right) \mathrm{Cl}\right]\left(\mathrm{NO}_{3}\right)$ (2). Red solid. Yield: $266 \mathrm{mg}$ (76\%, 0.34 mmol). Anal. Calcd for $\mathrm{C}_{18} \mathrm{H}_{23} \mathrm{BClF}_{2} \mathrm{IN}_{6} \mathrm{O}_{3} \mathrm{Pt}\left(M_{\mathrm{w}}\right.$ : 777.6663): C, 27.80; H, 2.98; N, 10.81. Found: C, 27.99; H, 3.20; N, 10.57. HRMS $\mathrm{m} / z$ : Calcd for $\left[\mathrm{M}-\mathrm{NO}_{3}\right]^{+}, 715.0396$; Found, 715.0303. ${ }^{1} \mathrm{H}$ NMR $\left(400 \mathrm{MHz}, \mathrm{CDCl}_{3}\right): 7.86(\mathrm{~d}, J=8.73,2 \mathrm{H}), 7.64(\mathrm{~d}, J=9.1,2 \mathrm{H}), 5.95$ (s, 1H), $4.20(\mathrm{~s}, 3 \mathrm{H}), 3.82(\mathrm{~s}, 3 \mathrm{H}), 2.52(\mathrm{~s}, 6 \mathrm{H}), 1.41(\mathrm{~s}, 3 \mathrm{H}), 1.31(\mathrm{~s}$, $3 \mathrm{H}) .{ }^{13} \mathrm{C}$ NMR $\left(100 \mathrm{MHz} \mathrm{CDCl}_{3}\right): \delta 160.85,155.95,155.86,152.83$, $148.06,144.12,137.65,130.99,122.57,87.45,39.67,36.26,17.43$, 16.63 ppm. ${ }^{11} \mathrm{~B}$ NMR $\left(100 \mathrm{MHz}\right.$, DMSO- $\left.d_{6}\right): 0.58(\mathrm{t}, 1 \mathrm{~B}) .{ }^{19} \mathrm{~F}$ NMR $\left(100 \mathrm{MHz}, \mathrm{DMSO}-d_{6}\right):-145.66$ (quartet, $\left.2 \mathrm{~F}\right)$. UV-visible $(1 \%$ DMSO/DMEM at $\mathrm{pH} 7.2)\left[\lambda_{\max }, \mathrm{nm}\left(\varepsilon, \mathrm{M}^{-1} \mathrm{~cm}^{-1}\right)\right]: 525(20100)$, 490 (7450 sh), 374 (3060). Emission (1\% DMSO/DMEM at $\mathrm{pH}$ 7.2): $\lambda_{\mathrm{em}}\left(\lambda_{\mathrm{ex}}, \Phi_{\mathrm{F}}\right)=540 \mathrm{~nm}(505 \mathrm{~nm}, 0.02)$.
Cis- $\left[\mathrm{Pt}\left(\mathrm{NH}_{3}\right)_{2}\left(\mathrm{~L}^{3}\right) \mathrm{Cl}\right]\left(\mathrm{NO}_{3}\right)$ (3). Red solid. Yield: $297 \mathrm{mg}$ (73\%, 0.32 mmol). Anal. Calcd for $\mathrm{C}_{18} \mathrm{H}_{22} \mathrm{BClF}_{2} \mathrm{I}_{2} \mathrm{~N}_{6} \mathrm{O}_{3} \mathrm{Pt}\left(M_{\mathrm{w}}\right.$ : 903.5627): C, 23.99; H, 2.45; N, 9.30. Found: C, 24.22; H, 2.73; N, 8.97. HRMS $m /$

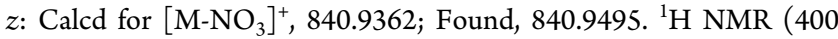
MHz, DMSO- $\left.d_{6}\right): \delta 8.93(\mathrm{~d}, J=9.23,2 \mathrm{H}), 7.92(\mathrm{~d}, J=7.29,2 \mathrm{H})$, $4.76(\mathrm{~s}, 3 \mathrm{H}), 4.55(\mathrm{~s}, 3 \mathrm{H}), 2.55(\mathrm{~s}, 6 \mathrm{H}), 1.39(\mathrm{~s}, 6 \mathrm{H}) .{ }^{13} \mathrm{C}$ NMR $(100$ $\left.\mathrm{MHz}, \mathrm{CDCl}_{3}\right): \delta 159.03,157.07,154.48,149.69,130.16,128.02$, 124.14, 87.64, 31.47, $16.71 \mathrm{ppm} .{ }^{11} \mathrm{~B}$ NMR (100 MHz, DMSO- $\left.d_{6}\right)$ : 0.59 (t, 1B). ${ }^{19} \mathrm{~F}$ NMR (100 MHz, DMSO- $\left.d_{6}\right):-145.96$ (quartet, $2 \mathrm{~F})$. UV-visible (1\% DMSO/DMEM at $\mathrm{pH} 7.2)\left[\lambda_{\max }, \mathrm{nm}\left(\varepsilon, \mathrm{M}^{-1}\right.\right.$ $\left.\mathrm{cm}^{-1}\right)$ ]: 555 (11 000), 398 (4050).

Cis- $\left[\mathrm{Pt}\left(\mathrm{NH}_{3}\right)_{2}\left(\mathrm{~L}^{4}\right) \mathrm{Cl}\right]\left(\mathrm{NO}_{3}\right)$ (4). White solid. Yield: $141.6 \mathrm{mg}$ (75\%, $0.34 \mathrm{mmol})$. Anal. Calcd for $\mathrm{C}_{6} \mathrm{H}_{13} \mathrm{ClN}_{4} \mathrm{O}_{3} \mathrm{Pt}\left(M_{\mathrm{w}}\right.$ : 419.7290): C, 17.17; H, 3.12; N, 13.35. Found: C, 16.87; H, 3.01; N, 13.17. HRMS

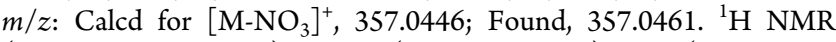
$\left(400 \mathrm{MHz}, \mathrm{DMSO}-d_{6}\right): \delta 8.56(\mathrm{~d}, J=7.54,2 \mathrm{H}), 7.45(\mathrm{~d}, J=8.49$, $2 \mathrm{H}), 4.60(\mathrm{~s}, 3 \mathrm{H}), 4.25(\mathrm{~s}, 3 \mathrm{H}), 2.39(\mathrm{~s}, 3 \mathrm{H}) .{ }^{13} \mathrm{C}$ NMR $(100 \mathrm{MHz}$, DMSO- $\left.d_{6}\right): \delta 152.89,152.45,128.40,127.69,31.60$. UV-visible (1\% DMSO/DMEM at $\mathrm{pH} 7.2)\left[\lambda_{\max }, \mathrm{nm}\left(\varepsilon, \mathrm{M}^{-1} \mathrm{~cm}^{-1}\right)\right]: 565(1400)$, 377 (300).

Crystal Structure and Theoretical Method. Complex 4 and the ligands $\mathrm{L}^{1}, \mathrm{~L}^{2}$, and $\mathrm{L}^{3}$ were structurally characterized by single-crystal $\mathrm{X}$-ray diffraction. Complex $\mathbf{4}$ was crystallized as colorless rectangular blocks obtained from slow evaporation of saturated solutions of 4 in methanol, while $\mathrm{L}^{1}-\mathrm{L}^{3}$ were crystallized as red colored rectangular blocks from their dichloromethane solution on slow evaporation. Paratone oil was used to mount the crystals on loops. All intensity and geometric data were collected using an automated Bruker SMART APEX (D8 QUEST) CMOS diffractometer with the SMART/SAINT software equipped with a Mo-K $\alpha$ X-ray source $(\lambda=0.71073 \AA)$ with increasing $\omega$ (width of $1^{\circ}$ per frame) at a scan speed of $10 \mathrm{~s}$ frame $^{-1}$. Intensity data were collected using $\omega$ - $2 \theta$ scan mode and then corrected for Lorentz-polarization and absorption effects. ${ }^{27}$ The structures were solved by direct methods and Fourier analysis and refined by the full-matrix least-squares method based on $F^{2}$ with all observed reflections using the SHELX-13 program incorporated into WinGX (2013). ${ }^{27 b}$ Anisotropic displacement coefficients were used to refine the non-hydrogen atoms, and their coordinates were permitted to ride on their respective carbon atoms. Anisotropic thermal parameters for the non-hydrogen atoms and isotropic thermal parameters for the hydrogen atoms were included in the final refinement. The perspective views were obtained using ORTEP. ${ }^{27 c}$ Selected crystallographic parameters, bond distances and angles are given in Tables S1-S3 (see Supporting Information). The CCDC deposition numbers are 1821177-1821180. The geometries of the complexes were optimized using basis sets and B3LYP/LANL2DZ level of density functional theory (DFT) calculations. ${ }^{28,29}$

Cellular Experiments. Experimental procedures used for the cellular studies are given in Supporting Information. The MTT, 3(4,5-dimethylthiazol-2-yl)-2,5-diphenyltetrazolium bromide, assay was done using three types of cells, namely, A549 (human lung carcinoma), MCF-7 (human breast adenocarcinoma), and $\mathrm{HaCaT}$ (immortalized human keratinocytes), in DMEM (Dulbecco's Modified Eagle's Medium) supplemented with $10 \%$ fetal bovine serum (FBS) to obtain the half maximal inhibitory concentration $\left(\mathrm{IC}_{50}\right)$ values. Visible light source $(1 \mathrm{~h}$ exposure, $\lambda=400-700 \mathrm{~nm}$, light dose $=10 \mathrm{~J} \mathrm{~cm}^{-2}$ ) using a Luzchem photoreactor (model LZC-1, Ontario, Canada) fitted with eight fluorescent white tubes of Sylvania make was used for photoexposure of one set of cells, whereas the other set was kept in the dark for $1 \mathrm{~h}^{8}$ A TECAN microplate reader was used, and graphs were plotted by using GraphPad Prism 7 software. Intracellular ROS measurement was done from a 2,7dichlorofluorescein diacetate (DCFDA) assay. The percentage population of cells generating ROS was determined by flow cytometric analysis. The cells $\left(3.0 \times 10^{5}\right.$ A549 cells) were incubated with the complexes 1-3 $(1 \mu \mathrm{M})$ along with their respective free ligands $\mathrm{L}^{1}-\mathrm{L}^{3}(1 \mu \mathrm{M})$ and control complex $4(10 \mu \mathrm{M})$ for $4 \mathrm{~h}$. One set of the cells was photoexposed to visible light $(400-700 \mathrm{~nm}, 1 \mathrm{~h}$ ), while the other set was kept in the dark. The cells were harvested by trypsinization, and a single cell suspension was prepared. The cells 
were subsequently treated with $1 \mu \mathrm{M}$ DCFDA solution prepared in DPBS (Dulbecco's phosphate-buffered saline) in the dark for $20 \mathrm{~min}$ at room temperature. The distribution of DCFDA stained A549 cells was obtained by flow cytometry in the FL-1 channel. Cellular localization was studied from confocal fluorescence imaging of the complexes $1(1 \mu \mathrm{M}), 2(10 \mu \mathrm{M})$, and ligand $\mathrm{L}^{1}(5 \mu \mathrm{M})$ in $1 \%$ DMSO/DMEM on a Carl Zeiss Microscopy and images were acquired with the help of ZEN lite software. Complex 3 was not used for this study for its nonemissive properties. Mitotracker Deep Red (MTR, $100 \mathrm{nM}$ ) and DAPI (300 nM, 4',6-diamidino-2-phenylindole) were used as mitochondria and nuclear staining agents, respectively.

Cellular apoptosis was studied from Annexin V-FITC/PI assay. Propidium iodide (PI) was used to stain necrotic cells with red fluorescence. A549 cells $\left(3.0 \times 10^{5}\right)$ and the complexes $2,3(0.1 \mu \mathrm{M})$, and $4(10 \mu \mathrm{M})$ were plated in six-well plates and cultured for $24 \mathrm{~h}$. Photoirradiation $(400-700 \mathrm{~nm}, 1 \mathrm{~h})$ was done for one set in DPBS. The cells were resuspended in $1 \times$ binding buffer. Annexin V-FITC and PI were added. The fluorescence of the cells was measured with a flow cytometer. Cells undergoing early apoptosis were stained with the annexin V-FITC alone. Cell cycle analysis experiment was performed to quantify the DNA content of the cell by flow cytometry. Propidium iodide (PI) was used as nuclear DNA binding agent. On the basis of the fluorescence intensity, the cells were distinguished into different phases of the cell cycle. A549 cells used for this experiment were treated with the complex ( 2 and 3 of $0.1 \mu \mathrm{M}$ and 4 of $10 \mu \mathrm{M})$ in dark or on $1 \mathrm{~h}$ of photoirradiation $(400-700 \mathrm{~nm})$. Hypotonic citrate stain in $0.10 \%$ trisodium citrate dihydride containing $0.10 \%$ Triton X-100 was used. The cell suspension was centrifuged, and the nuclear pellet was resuspended in fresh hypotonic citrate stain supplemented to $50 \mu \mathrm{g} \mathrm{mL}^{-1}$ PI for FACS analysis.

DNA Photocleavage Experiments. UV-visible spectral titration studies were made to obtain the calf thymus (ct) DNA binding constants of the complexes. The supercoiled (SC) plasmid pUC19 DNA photocleavage activity of the complexes was studied using a CW (continuous wave) diode laser $(532 \mathrm{~nm}, 100 \mathrm{~mW}$ power, $1 \mathrm{~h}$ exposure time, $0.32 \pm 0.02 \mathrm{~mm}$ beam diameter, Research Electro-Optics model no. EXLSR-532-100-CDRH, Colorado, U.S.A.) for photoirradiation followed by gel electrophoresis. Mechanistic studies were conducted to determine the nature of ROS such as hydroxyl radicals $\left({ }^{\bullet} \mathrm{OH}\right)$, superoxide radicals and singlet oxygen $\left({ }^{1} \mathrm{O}_{2}\right)$ by using different external additives, namely, DMSO, KI, catalase as hydroxyl radical scavengers, TEMP (2,2,6,6-tetramethyl-4-piperidone), and sodium azide as singlet oxygen quenchers and superoxide dismutase (SOD) as superoxide scavenger.

\section{RESULTS AND DISCUSSION}

Synthesis and Characterization. The pyridyl ligands $\mathrm{L}^{1}-$ $\mathrm{L}^{3}$ having the BODIPY pendants were synthesized using literature procedures with modifications (Scheme 1). ${ }^{8 b, 21}$ The monofunctional platinum(II) complexes, cis- $\left[\mathrm{Pt}\left(\mathrm{NH}_{3}\right)_{2}(\mathrm{~L})\right.$ $\mathrm{Cl}]\left(\mathrm{NO}_{3}\right)(1-4)$, where $\mathrm{L}$ is BODIPY conjugated pyridyl ligands $\mathrm{L}^{1}-\mathrm{L}^{3}$ (in 1-3) and 4-methylpyridine (in 4), were synthesized following a common procedure in which a solution of cisplatin in $N, N$ - dimethylformamide (DMF) was initially treated with silver nitrate, and after removal of the silver chloride precipitate from the filtrate, respective ligand (L) was added to isolate the product as their nitrate salt in good yield. The complexes were characterized from the elemental analytical and spectral data (Figures S1-S32, Supporting Information). Selected physicochemical data are given in Table 1. The BODIPY derivatives $\mathrm{L}^{1}-\mathrm{L}^{3}$ and the control complex 4 were structurally characterized by single-crystal X-ray crystallography (Figure 2, Tables S1-S3, Figures S33-S39, Supporting Information). ${ }^{27}$ Density functional theory (DFT) calculations using B3LYP/LANL2DZ were done to optimize the structures of 1-4 (Figure 2, Table S4, Figure S40, Supporting Information). ${ }^{2,29}$ The IR spectra exhibited
Table 1. Selected Physiochemical Data for the Complexes 1-3 and Ligands $\mathrm{L}^{1}-\mathrm{L}^{3}$

$\begin{array}{cccccc}\text { compound } & \begin{array}{c}\Lambda_{\mathrm{M}}{ }^{a} / \mathrm{S} \\ \mathrm{m}^{2} \mathrm{M}^{-1}\end{array} & \begin{array}{c}\lambda_{\text {max }} / \mathrm{nm} \\ \left(\times 10^{-4} \varepsilon / \mathrm{M}^{-1}\right. \\ \left.\mathrm{cm}^{-1}\right)^{b}\end{array} & \begin{array}{c}\lambda_{\text {em }} / \mathrm{nm} \\ \left(\Phi_{\mathrm{F}}\right)^{c}\end{array} & \begin{array}{c}\mathrm{Log} \\ P_{\mathrm{O}} / \\ \mathrm{W}\end{array} & \begin{array}{c}\Phi_{\Delta} \\ \left({ }^{1} \mathrm{O}_{2}\right)^{e}\end{array} \\ \mathbf{1} & 74 & \begin{array}{c}505(4.1), \\ 475(1.1)\end{array} & 530(0.07) & 0.85 & 0.26 \\ & & & & \\ 2 & 73 & \begin{array}{c}525(2.01), 490 \\ (0.7 \mathrm{sh})\end{array} & 540(0.02) & 0.97 & 0.48 \\ 3 & 76 & 555(1.1) & & & \\ \mathrm{L}^{1} & & 505(9.6) & 515(0.19) & 2.51 & 0.21 \\ \mathrm{~L}^{2} & & 525(6.3) & 535(0.08) & 2.69 & 0.37 \\ \mathrm{~L}^{3} & & 550(4.7) & & 2.76 & 0.49\end{array}$

${ }^{a}$ Molar conductivity in DMF. ${ }^{b}$ In $1 \%$ DMSO/DMEM solution. ${ }^{c}$ Emisssion wavelength and fluorescence quantum yield. Complex 3 and $\mathrm{L}^{3}$ are nonemissive. ${ }_{n}$-Octanol/water partition coefficient. $e^{e}$ singlet oxygen quantum yield in air-saturated DMSO/DMF.

characteristic bands of the free ligands and their respective complexes in accordance to their formulations. The $\mathrm{N}-\mathrm{H}$ in $\mathrm{Pt}-\mathrm{NH}_{3}$ appeared as a broad peak near $3300-3100 \mathrm{~cm}^{-1}$ (Figures S29-S32, Supporting Information). ${ }^{8 \mathrm{~b}}$

NMR and Mass Spectral Studies. The purity and formulation of these Pt-BODIPY complexes $\mathbf{1 - 4}$ were ascertained from their ${ }^{1} \mathrm{H},{ }^{11} \mathrm{~B},{ }^{13} \mathrm{C}$, and ${ }^{19} \mathrm{~F} N \mathrm{NMR}$ and HPLC spectral data (Figures S1-S21, Supporting Information). The aromatic hydrogen protons appearing in the range of $8.89-7.50 \mathrm{ppm}$ are due to the pyridyl groups of the BODIPY ligands alone, while they appear downfield shifted within 8.90-8.76 ppm for the complexes due to coordination of the pyridyl group to platinum(II) (Figures S1-S7, Supporting Information). The absence of alpha proton signals in BODIPY ligand $\mathrm{L}^{3}$ within $6.25-6.10 \mathrm{ppm}$ is due to diiodination of the BODIPY core when compared to its noniodo and monoiodo analogues showing the signals at 6.25 and $6.00 \mathrm{ppm}$ in their respective complexes. The signals observed within $2.46-2.40$ and $1.40-1.31 \mathrm{ppm}$ are assignable to the pyrrolic methyl protons of BODIPY. Two additional signals for the ammine protons are in the range of 4.80-4.15 ppm for all the complexes. The ${ }^{13} \mathrm{C}$ NMR spectra showed peaks in the range of $160-120 \mathrm{ppm}$ for aromatic carbon atoms, and the peaks within $40-15 \mathrm{ppm}$ are for aliphatic methyl carbons. The peaks corresponding to iodinated carbon atoms were observed at $\sim 86 \mathrm{ppm}$ in ${ }^{13} \mathrm{C}$ NMR of complexes 3 and 4 (Figures S8-S14, Supporting Information). The ${ }^{11} \mathrm{~B}$ NMR showed a characteristic triplet signal in the range of 0.84-0.29 ppm of the boron nuclei, resulting from coupling of two equivalent fluorine nuclei of the $\mathrm{BF}_{2}$ moiety with a coupling constant of $29 \mathrm{~Hz}$. The effect of iodination in $\mathrm{L}^{1}$ on the boron atom is seen from the downfield shift from 0.03 and $0.07 \mathrm{ppm}$ in the ${ }^{11} \mathrm{~B}$ NMR of ligand $\mathrm{L}^{2}$ (Figures S15-S17, Supporting Information). A small change in the symmetry of the BODIPY unit makes a notable change in the NMR spectra of the ${ }^{19} \mathrm{~F}$ signal. Both noniodo and monoiodo BODIPY ligands $\mathrm{L}^{1}$ and $\mathrm{L}^{2}$ showed a single quartet, whereas it is a quintet spectrum for the di-iodo ligand $\mathrm{L}^{3}$ (Figures S18-S20, Supporting Information).

The compositions of the ligands and their platinum complexes were investigated by HRMS. The ligands $\mathrm{L}^{1}-\mathrm{L}^{3}$ displayed peaks corresponding to their respective molecular ion peaks in $\mathrm{MeOH}$. Complexes 1-4 as nitrate salts exhibited primary peaks assignable to $\left[\mathrm{M}-\mathrm{NO}_{3}\right]^{+}$. The isotopic distribution pattern in $\mathbf{1 - 4}$ indicated the charge carried by 
(a)

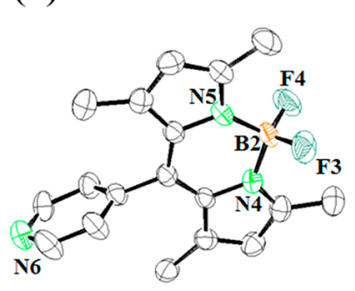

(d) $\bigoplus_{03}^{\mathrm{N} 4}$

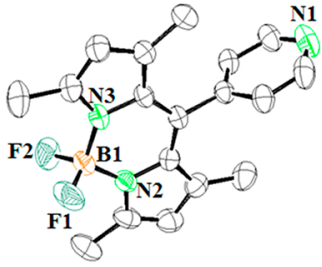

(b)

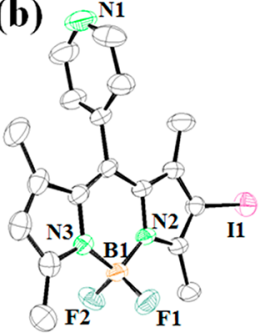

(e)

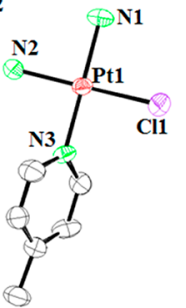

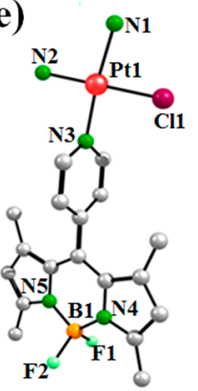

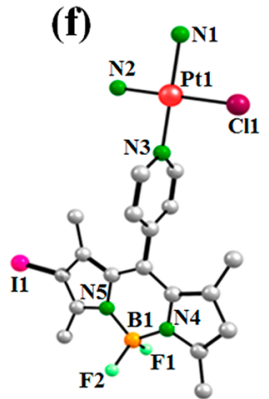

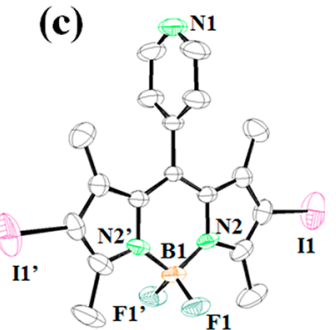

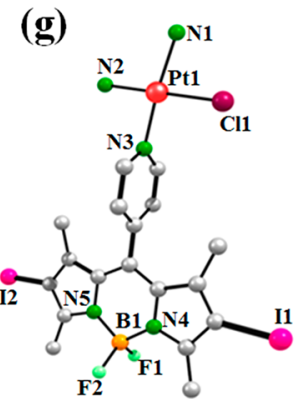

Figure 2. ORTEP views of the ligands $\mathrm{L}^{1}$ (a), $\mathrm{L}^{2}(\mathrm{~b}), \mathrm{L}^{3}$ (c), and the monocationic complex of 4 (d) showing thermal ellipsoids at the $50 \%$ probability level and the numbering scheme for the hetero atoms and the metal. The energy minimized structures of complexes 1 (e), 2 (f), and 3 (g) using B3LYP/LANL2DZ level of theory. Color codes: Pt, red; I, pink; Cl, purple; F, sea green; O, blue; N, green; C, black; B, orange red.

platinum(II) complexes as unipositive (Figures S22-S28, Supporting Information). The molecular structures of the ligands $\mathrm{L}^{1}-\mathrm{L}^{3}$ and complex 4 as a control species were obtained from X-ray crystallography.

Crystallography and Theoretical Study. Ligands $\mathrm{L}^{1}-\mathrm{L}^{3}$ and complex 4 were structurally characterized by single crystal X-ray crystallography (Figure 2, Tables S1-S3, Figures S33S39, Supporting Information). ${ }^{27}$ Ligand $\mathrm{L}^{1}$ crystallized in the orthorhombic space group $P n a 2_{1}$, whereas $\mathrm{L}^{2}$ and $\mathrm{L}^{3}$ crystallized in the monoclinic and orthorhombic space group $P 2_{1} / \mathrm{c}$ and $\mathrm{Cmcm}$, respectively. The asymmetric unit of the crystal lattice of $\mathrm{L}^{1}$ has two molecules of the ligand, whereas ligand $\mathrm{L}^{2}$ and $\mathrm{L}^{3}$ has one molecule in the crystallographic asymmetric unit. Complex 4 crystallized in the monoclinic space group $P 2_{1} / \mathrm{c}$. The nitrate ion is present as counteranion in the cationic complex 4 (Figure 2a). The complex having platinum(II) coordinated to three $\mathrm{N}$-donor atoms, has a square planar geometry with two ammine groups cis to each other, a pyridyl moiety, and a chloride ligand. The $\mathrm{Pt}-\mathrm{N}$ bond distances in 4 are $\sim 2.0 \AA$. The $\mathrm{Pt}-\mathrm{Cl}$ distance is 2.299(4) $\AA$, and the $\mathrm{H}_{3} \mathrm{~N}-\mathrm{Pt}-\mathrm{NH}_{3}$ angle is $90.390(6)^{\circ}$. The $\mathrm{Pt}-\mathrm{Cl}$ bonds of 2.308(19) and 2.313(2) $\AA$ in cisplatin are essentially similar to those observed in complex $4 .^{8 \mathrm{~b}}$ The unit cell packing diagram of 4 showed chemically significant hydrogen bonding interactions between the hydrogen atoms of the ammine group with the nitrate counteranion and the chloride ligand.

The structural data of ligands $\mathrm{L}^{1}-\mathrm{L}^{3}$ and complex 4 from $\mathrm{X}$ ray crystallography were used to generate the energy optimized structures of the complexes $1-3$ by quantum calculations with B3LYP/LANL2DZ level of theory for all atoms (Figure $2 \mathrm{e}-\mathrm{g}$, Table S4, Figure S40, Supporting Information). ${ }^{27,28}$ The frontier orbitals were mapped on the atoms from the distribution of the electronic charge density. The HOMO of the BODIPY complexes is localized on the Pt-pyridyl core, while LUMO is localized on the BODIPY moiety.

Electronic Spectra. The Pt-BODIPY conjugates $\mathbf{1 - 3}$ and related free ligands $\mathrm{L}^{1}-\mathrm{L}^{3}$ (5 and $10 \mu \mathrm{M}$ ) were studied by $\mathrm{UV}-$ visible absorption and fluorescence spectroscopy in $1 \%$
DMSO/DMEM buffer of $\mathrm{pH}=7.2$ (Figure 3, Table 1, Figure S41, Supporting Information). The complexes displayed
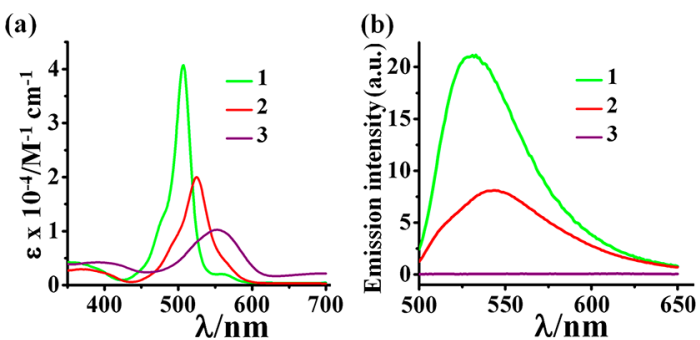

Figure 3. (a) Absorption and (b) emission spectra $\left(\lambda_{\text {ex }}=490 \mathrm{~nm}\right)$ of the complexes 1-3 $(5 \mu \mathrm{M})$ in $1 \%$ DMSO-DMEM solution $(\mathrm{pH}=$ 7.2) [color code: green, 1; red, 2; purple, 3 ].

intense absorption bands within 505-555 $\mathrm{nm}$ that are assignable to the electronic transition within the BODIPY core (Figure 3a). ${ }^{30}$ Complex 1 showed an intense emission band at $530 \mathrm{~nm}\left(\lambda_{\mathrm{ex}}=490 \mathrm{~nm}\right)$ assignable to the noniodo BODIPY moiety (Figure $3 \mathrm{~b}$ ). A modest intensity emission band for monoiodo BODIPY complex 2 was observed at 540 $\mathrm{nm}\left(\lambda_{\mathrm{ex}}=505 \mathrm{~nm}\right)$. These emissive complexes were used for cellular imaging study. Incorporation of iodine atom to the noniodo BODIPY ligand $\left(\mathrm{L}^{1}\right)$ caused a red shift of ca. 25 and $45 \mathrm{~nm}$ of the absorption maximum for the monoiodo-BODIPY $\left(\mathrm{L}^{2}\right)$ and diiodo-BODIPY $\left(\mathrm{L}^{3}\right)$ ligands. This red shift is also observed for the complexes 2 and 3. Like the absorption spectra, iodination-induced red shift was detected in the emission spectra of the ligands and the complexes. The presence of the heavy atom iodine resulted in a decrease in the fluorescence quantum yield $\left(\Phi_{\mathrm{F}}\right)$ values from 0.19 for noniodinated $\mathrm{L}^{1}$ to 0.08 for monoiodinated $\mathrm{L}^{2}$ and 0.04 for diiodinated $\mathrm{L}^{3}$.

Upon binding to the platinum(II) center, the fluorescence quantum yields of $\mathrm{L}^{1}$ and $\mathrm{L}^{2}$ get reduced further to 0.07 for 1 and 0.02 for 2 . Complex 3 did not display any emission band, whereas a weak emissive band was observed for ligand $L^{3}$. The 
attachment of heavy iodine atoms in the BODIPY ligand and the platinum core together make the intersystem crossing (ISC) facile for 3, thus resulting in reduced fluorescence intensity. ISC facilitates the type-II process resulting in the generation of singlet oxygen species by the energy transfer pathway from triplet complex 3 to triplet molecular oxygen. ${ }^{31,32}$ Complex $\mathbf{3}$ as a photosensitizer is found to be suitable for the PDT study in visible light.

Singlet Oxygen as the ROS. PDT causes cancer cell death by generating reactive oxygen species (ROS) in which singlet oxygen $\left({ }^{1} \mathrm{O}_{2}\right)$ is the preferred ROS in PDT as there is no apparent defense mechanism for this highly reactive species in our human body. Iodine atoms in the BODIPY core cause the heavy atom effect resulting in an enhancement of the singlet oxygen quantum yield. Singlet oxygen as the ROS was probed from a trap experiment in UV-visible spectral titration using 1,3-diphenylisobenzofuran (DPBF), which is a fluorescent dye used specifically for singlet oxygen detection. The noniodo BODIPY complex $\mathbf{1}$, monoiodo-BODIPY complex $\mathbf{2}$, diiodo-BODIPY complex 3 , and their free ligands $\mathrm{L}^{1}-\mathrm{L}^{3}$ in 5 $\mu \mathrm{M}$ concentration were studied using DPBF $(50 \mu \mathrm{M})$ in noncellular air saturated DMF medium (Figure 4a). A gradual
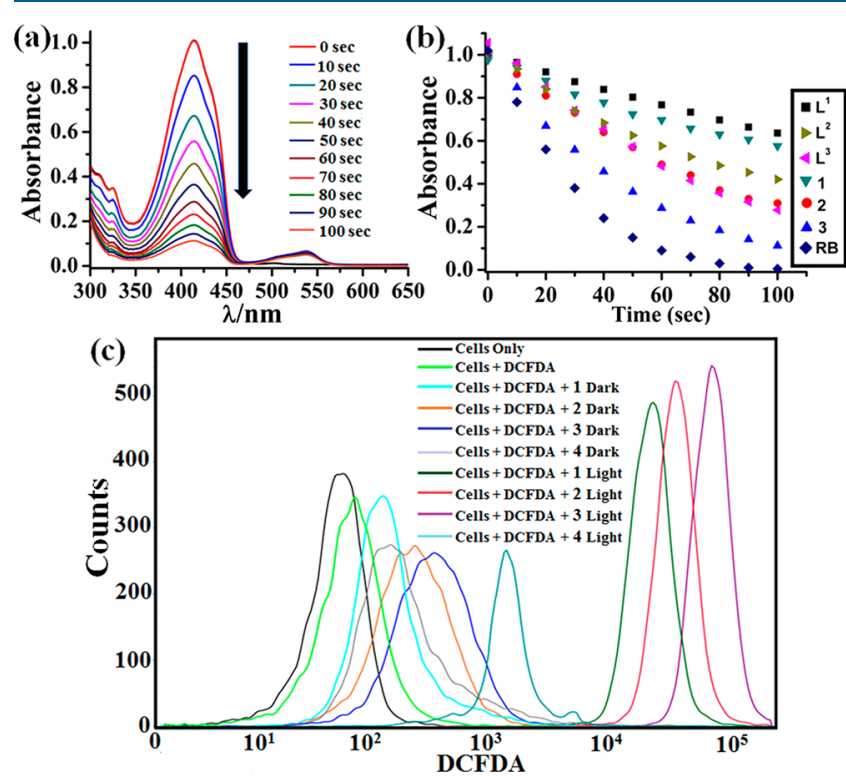

Figure 4. (a) Spectral changes of DPBF $(50 \mu \mathrm{M})$ at $415 \mathrm{~nm}$ with time on treatment with complex 3 in air saturated DMF. (b) Plot showing the change in absorbance of DPBF at $\sim 415 \mathrm{~nm}$ vs photoirradiation time in the presence of Rose Bengal (RB) (purple), ligands $\mathrm{L}^{1}$ (black), $\mathrm{L}^{2}$ (green), and $\mathrm{L}^{3}$ (pink), complexes 1 (cyan), 2 (red), and 3 (blue). The observed order of the slope: $\mathrm{RB}>3>\mathrm{L}^{3} \geq 2>\mathrm{L}^{2}>1>$ $\mathrm{L}^{1}$. (c) DCFDA assay showing shift in the band position of the complexes 1-4 in A549 cells in light $\left(400-700 \mathrm{~nm}, J \mathrm{~cm}^{-2}\right)$ with color code: black, cells only; green, cells + DCFDA; cells + DCFDA + complexes $\mathbf{1}$ (cyan), $\mathbf{2}$ (orange), $\mathbf{3}$ (blue), and $\mathbf{4}$ (gray) in dark and $\mathbf{1}$ (green), $\mathbf{2}$ (pink), 3 (purple), and $\mathbf{4}$ (greenish-blue) on $1 \mathrm{~h}$ exposure to visible light $(400-700 \mathrm{~nm})$.

decrease in the intensity of the band at $415 \mathrm{~nm}$ of DPBF at different time intervals upon photoexposure using a photoreactor $\left(\lambda=400-700 \mathrm{~nm}, 10 \mathrm{~J} \mathrm{~cm}^{-2}\right)$ gave an estimate of the extent of singlet oxygen generation (Figure $4 \mathrm{a}$, Figures S42, S43, Supporting Information). The plot revealed that the iodinated BODIPY complexes $\mathbf{2}$ and $\mathbf{3}$ with higher slopes are more efficient singlet oxygen generators than the noniodinated
BODIPY complex 1 and their respective free BODIPY ligands (Figure $4 \mathrm{~b})$. The singlet oxygen quantum yield $\left(\Phi_{\Delta}\right)$ for the complexes and the ligands was measured using Rose Bengal as the standard having a $\Phi_{\Delta}$ value of 0.76 (Table 1$) .{ }^{33}$ The efficacy of singlet oxygen generation of the complexes follows the order: $\mathbf{3}>\mathbf{2}>\mathbf{1} \gg \mathbf{4}$. The non-BODIPY complex 4 did not show any apparent change in the DPBF intensity on photoirradiation. The results highlight the importance of the BODIPY moieties in the complex design for generation of singlet oxygen in visible light. The $\Phi_{\Delta}$ values of the pyriplatin$B$ complexes showed a higher trend in singlet oxygen generation than their imidazoplatin-B analogues possibly due to more efficient ISC in pyriplatin-B complexes in the presence of the pyridyl group directly attached to the BODIPY core without having any $-\mathrm{CH}_{2}-$ spacer.

Intracellular ROS. 2,7-Dichlorofluorescein diacetate (DCFDA) is a nonpolar fluorescent dye used to measure the intracellular ROS. ${ }^{34} \mathrm{H}_{2}$ DCFDA on diffusion into the cell gets deacetylated by enzymatic reaction. The nonfluorescent compound converts to a fluorescent molecule 2,7-dichlorofluorescein (DCF) upon oxidation by ROS. To determine the percentage population of cells generating ROS, A549 lung cancer cells were incubated with the complexes 1-3 along with their free ligands $\mathrm{L}^{1}-\mathrm{L}^{3}(1 \mu \mathrm{M})$ and control complex 4 (10 $\mu \mathrm{M}$ ) for $4 \mathrm{~h}$ in dark and then exposed to visible light (400$700 \mathrm{~nm}$ ) for $1 \mathrm{~h}$. After $19 \mathrm{~h}$ post incubation, flow cytometry was done for quantification of the ROS in living cells by measuring the green fluorescence of DCF at $\lambda_{\mathrm{em}}$ of $525 \mathrm{~nm}$. Complexes 1-3 showed enhancement in the fluorescence intensity of DCF upon light exposure compared to the identical set kept in the dark.

Control complex 4 showed no apparent change in dark and light indicating its inability to generate any ROS (Figure 4c, Figure S44, Supporting Information). The pyriplatin-B derivatives display higher cellular ROS formation than the Imidazoplatin-B derivatives (Figure S45, Supporting Information). These results showed the heavy atom effect of platinum metal on the pyridyl group that is directly attached to the BODIPY core as compared to imidazoplatin-B where Pt metal is bonded to the imidazole moiety linked to BODIPY core with a nonconjugating spacer.

Cell Viability Assay. As PDT is primarily effective for neck, lung, bladder, esophageal and skin cancers, we have chosen human lung cancer A549 cells, human breast cancer MCF-7 cells, and human skin keratinocytes $\mathrm{HaCaT}$ cells for this study. ${ }^{35}$ The anticancer activity of the complexes 1-4 along with their respective free ligands $\mathrm{L}^{1}-\mathrm{L}^{3}$ was investigated in both dark and light $(\lambda=400-700 \mathrm{~nm})$ by 3-(4,5dimethylthiazol-2-yl)-2,5-diphenyltetrazolium bromide (MTT) assay (Figure 5, Figures S46-S51, Supporting Information). The half maximal inhibitory concentrations $\left(\mathrm{IC}_{50}\right)$ are listed in Table 2 where the complexes $\mathbf{1}-\mathbf{3}$ showed photocytotoxicity at nanomolar concentration in these cells with $\mathrm{IC}_{50}$ values ranging from 0.05 to $1.7 \mu \mathrm{M}$ in visible light ( $1 \mathrm{~h}$ exposure, $\lambda$ $=400-700 \mathrm{~nm}$, light dose $=10 \mathrm{~J} \mathrm{~cm}^{-2}$ ), while the ligands showed photocytotoxicity ranging from 0.11 to $29.8 \mu \mathrm{M}$. On the other hand, there was no appreciable cytotoxicity of these compounds in the dark $(73$ to $>100 \mu \mathrm{M})$. The observed 25and 40 -fold increase in photocytotoxicity for the respective complexes $\mathbf{2}$ and $\mathbf{3}$ compared to the noniodinated complex $\mathbf{1}$ is attributed to the heavy atom effect of the mono- and diiodinated BODIPY core in generating significant quantity of singlet oxygen. The higher cytotoxicity of Pt-BODIPY 

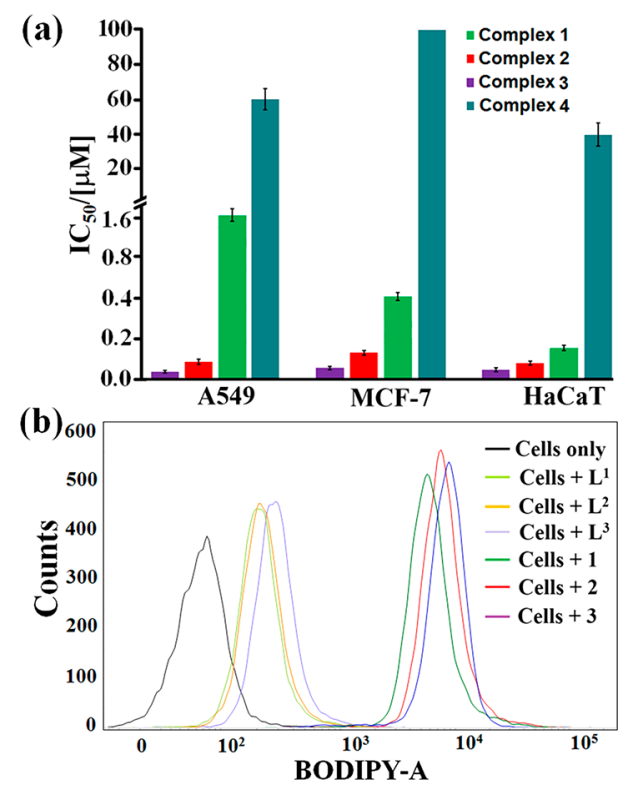

Figure 5. (a) Bar diagram for MTT assay data giving $\mathrm{IC}_{50}$ values in light for the complexes 1-3 in A549 lung cancer, MCF-7 breast cancer, and $\mathrm{HaCaT}$ skin keratinocyte cells upon $1 \mathrm{~h}$ photoirradiation in visible light $\left(\lambda=400-700 \mathrm{~nm}, 10 \mathrm{~J} \mathrm{~cm}^{-2}\right)$ [color code: purple, 3 ; red, 2; green, 1]. The $\mathrm{IC}_{50}$ values of complex 4 , cisplatin and the ligands are given in Table 2. (b) Quantitative Cellular uptake analysis by flow cytometry upon incubating A549 cells with complexes 1-3 (5 $\mu \mathrm{M})$ and their corresponding free ligands $(5 \mu \mathrm{M})$ at $37^{\circ} \mathrm{C}$ for $4 \mathrm{~h}$, with cells untreated as a control. The shift in the band position of the complexes 1-3 in A549 cancer cells clearly indicates that the complexes have a higher cellular uptake compared to their free ligands $\mathrm{L}^{1}-\mathrm{L}^{3}$. BODIPY-A represents green emission for positive cells.

derivatives in comparison to the ligands is possibly because these platinum(II) complexes could potentially act as monofunctional DNA cross-linking agents besides their PDT activity as is known for pyriplatin and its analogues. ${ }^{5,8 \mathrm{~b}}$ The potency of these complexes was compared in terms of photocytotoxicity with our previously reported ImidazoplatinB analogues using same batch of cells of A549, and it was found that pyriplatin-B has a higher activity as evidenced from the singlet oxygen quantum yield and cellular ROS generation results besides the MTT assay data (Figure S52, Supporting Information).
Cellular Uptake and Mitochondrial Localization. The therapeutic effect of a drug often depends on their cellular uptake. Complexes 1-3 with monocationic charge showed a substantial increase in the cellular uptake compared to their charge neutral free ligands in A549 cancer cells within $4 \mathrm{~h}$ of incubation (Figure $5 \mathrm{~b}) .^{5,21,22 a}$ This observation suggests a crucial role of the platinum metal in transporting the photosensitizer into the cells for better photoinduced cytotoxicity. These results are in good compliance with the oil/water partition coefficients, following the order: $\mathrm{L}^{1} \approx \mathrm{L}^{2} \approx$ $\mathrm{L}^{3} \gg 3>2>1$ (Table 1 ). The enhanced aqueous solubility of 1-3 is possibly due to the cationic charge and the presence of two ammine ligands bound to platinum(II). Co-localization experiments were used to measure the intracellular presence of the BODIPY-platinum conjugates. A549 cells were used for cellular imaging study considering that the complexes are highly PDT active in this cancer cell. The intracellular distribution pattern of the emissive ligand $\mathrm{L}^{1}$ and complexes 1 and 2 has been determined by confocal microscopy which displayed mitochondrial localization. Cytoplasmic localization was observed from the merged images of the ligand $\mathrm{L}^{1}(5 \mu \mathrm{M})$ and complexes $1(1 \mu \mathrm{M})$ and $2(10 \mu \mathrm{M})$ when treated with 4',6-diamidino-2-phenylindole (DAPI) as the nuclear staining dye after $4 \mathrm{~h}$ of incubation in dark (Figure 6, Figure S53, Supporting Information). The overlay image of the complexes and Mito-Tracker Deep Red (MTDR, $100 \mathrm{nM}$ ) revealed selective localization of the complexes into the mitochondria. This was further evidenced from the high Pearson's correlation coefficient (PCC) value of $\sim 0.8 .{ }^{8 \mathrm{~b}}$ Complex 3 being nonemissive was not used for any imaging study. Despite the colocalization of the complexes $\mathbf{1}$ and $\mathbf{2}$, the intracellular colocalization of ligand $\mathrm{L}^{2}$ was not observed as its cellular uptake was comparatively lower in comparison to their respective monocationic $\mathrm{Pt}(\mathrm{II})$ complexes upon $4 \mathrm{~h}$ incubation (Figure 6, Figure S53, Supporting Information). The predominant localization of pyriplatin-B in mitochondria is a major advantage over distributed localization of imidazoplatin$B$ between mitochondria and endoplasmic reticulum (ER).

Mitochondrial membrane potential $\left(\Delta \Psi_{\mathrm{m}}\right)$ was measured to investigate the mitochondria targeting ability of these PtBODIPY conjugates. JC-1 dye was used for the experiment as a ratiometric probe giving a direct insight into the functioning of the complex via fluorescence microscopy.

Table 2. Photocytotoxicity $\left(\mathrm{IC}_{50}\right.$ in $\left.\mu \mathrm{M}\right)$ and Mitochondrial Platinum Uptake Data for the Complexes $1-4$ and Ligands $\mathrm{L}^{1}-\mathrm{L}^{3}$

\begin{tabular}{|c|c|c|c|c|c|c|c|}
\hline \multirow[b]{2}{*}{ compounds } & \multicolumn{2}{|c|}{$\underline{\text { A549 }}$} & \multicolumn{2}{|c|}{$\underline{\text { MCF-7 }}$} & \multicolumn{2}{|c|}{$\underline{\mathrm{HaCaT}}$} & \multirow[b]{2}{*}{$\mathrm{Pt}(\mathrm{ng})^{c}$} \\
\hline & $(\text { light })^{a}$ & $(\text { dark })^{b}$ & $(\text { light })^{a}$ & $(\text { dark })^{b}$ & $(\text { light })^{a}$ & $(\text { dark })^{b}$ & \\
\hline $\mathbf{1}^{d, e}$ & $1.70 \pm 0.05$ & $94.4 \pm 1.2$ & $0.40 \pm 0.03$ & $>100$ & $1.0 \pm 0.04$ & $>100$ & $1.07 \pm 0.20$ \\
\hline 2 & $0.09 \pm 0.03$ & $>100$ & $0.13 \pm 0.02$ & $>100$ & $0.09 \pm 0.03$ & $>100$ & $1.12 \pm 0.13$ \\
\hline $3^{f}$ & $0.05 \pm 0.01$ & $73.2 \pm 1.1$ & $0.07 \pm 0.02$ & $>100$ & $0.06 \pm 0.02$ & $70.4 \pm 1.2$ & $1.14 \pm 0.16$ \\
\hline 4 & $60.3 \pm 1.4$ & $>100$ & $>100$ & $>100$ & $39.6 \pm 1.3$ & $>100$ & \\
\hline $\mathrm{L}^{1}$ & $11.5 \pm 0.1$ & $>100$ & $29.8 \pm 0.9$ & $>100$ & $7.2 \pm 0.1$ & $>100$ & nd \\
\hline $\mathrm{L}^{2}$ & $3.5 \pm 0.2$ & $>100$ & $3.7 \pm 0.1$ & $>100$ & $2.3 \pm 0.1$ & $>100$ & nd \\
\hline $\mathrm{L}^{3}$ & $0.30 \pm 0.06$ & $>100$ & $0.11 \pm 0.03$ & $>100$ & $0.50 \pm 0.01$ & $87.8 \pm 1.6$ & nd \\
\hline
\end{tabular}

${ }^{a}$ All the cells treated with the compounds for $4 \mathrm{~h}$ initial incubation in dark. ${ }^{b}$ Visible light $\left(1 \mathrm{~h}\right.$ photoexposure, $\left.400-700 \mathrm{~nm}, 10 \mathrm{~J} \mathrm{~cm}{ }^{-2}\right)$. Post photoexposure incubation time was $19 \mathrm{~h}$ in dark. ${ }^{c} \mathrm{~A} 549$ cells treated with the complexes $(100 \mu \mathrm{M})$ and the Pt content as Pt (ng/ng of mitochondria) determined by ICP-MS method. nd = not determined. ${ }^{d}$ The $\mathrm{IC}_{50} / \mu \mathrm{M}$ values reported for complex 1 in ref $21 \mathrm{a}$ are $27.37 \pm 1.14$ in HeLa and $12.14 \pm 2.44$ in MCF-7 cancer cells in the dark with $48 \mathrm{~h}$ incubation. ${ }^{e}{ }^{e}$ The $\mathrm{IC}_{50}$ values [light $\left.(400-700 \mathrm{~nm}) / \mathrm{dark}\right]$ of $\left[\mathrm{Pt}\left(\mathrm{NH}_{3}\right)_{2}\left(\mathrm{~L}_{1}\right) \mathrm{Cl}\right]^{+}$in A549, MCF-7 and HaCaT cells under identical conditions are $8.13 \pm 1.1 />100,2.8 \pm 0.7 />100$ and $0.76 \pm 1.3 / 100 \mu \mathrm{M}$

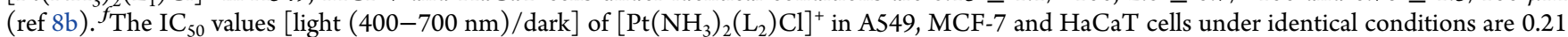
$\pm 0.04 />100,0.16 \pm 0.04 />50$ and $0.12 \pm 0.03 / 83.54 \pm 1.6 \mu \mathrm{M}$ (ref $8 \mathrm{~b})$. 


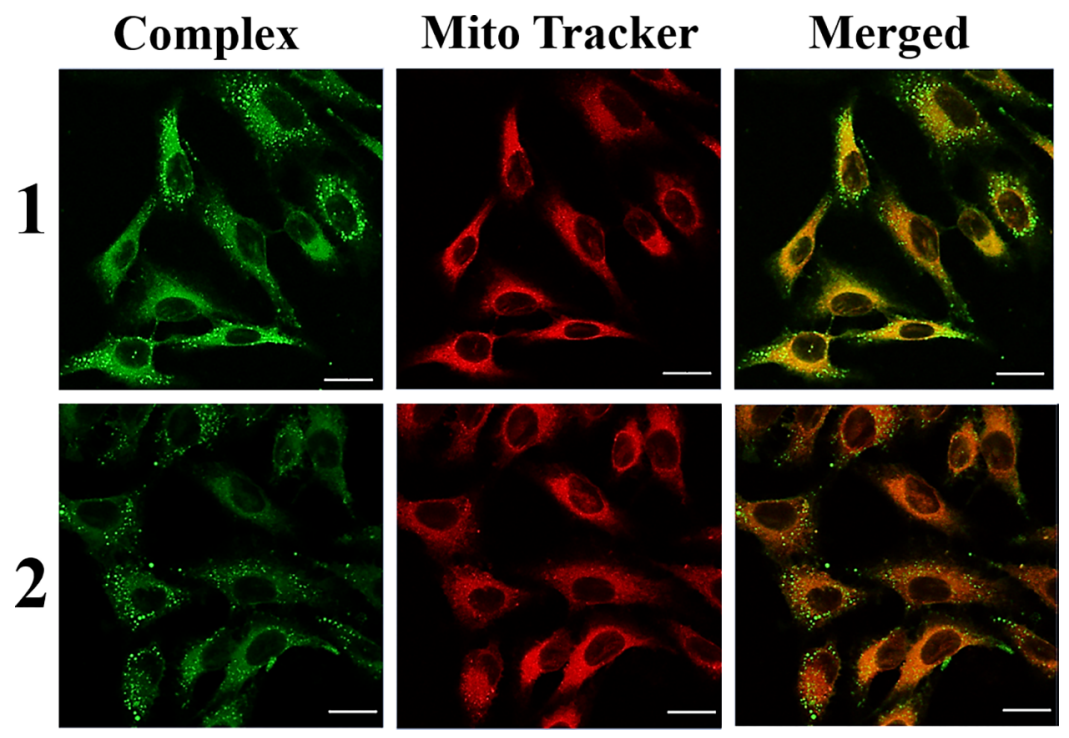

Figure 6. Confocal microscopic images of the noniodo BODIPY complex $1(5 \mu \mathrm{M})$ and monoiodo BODIPY complex $2(10 \mu \mathrm{M})$ showing green emission in A549 lung cancer cells on $4 \mathrm{~h}$ incubation in the dark in the left, the Mito-Tracker Deep Red (MTR) in the middle column, and the merged panels in the right column. The yellow/orange color in the right column indicates significant mitochondrial localization of the complexes. Scale bar $=10 \mu \mathrm{m}$. The fluorescence intensity being more for complex 1 than $\mathbf{2}$, the merged panel for $\mathbf{1}$ gave the desired intense yellow color.

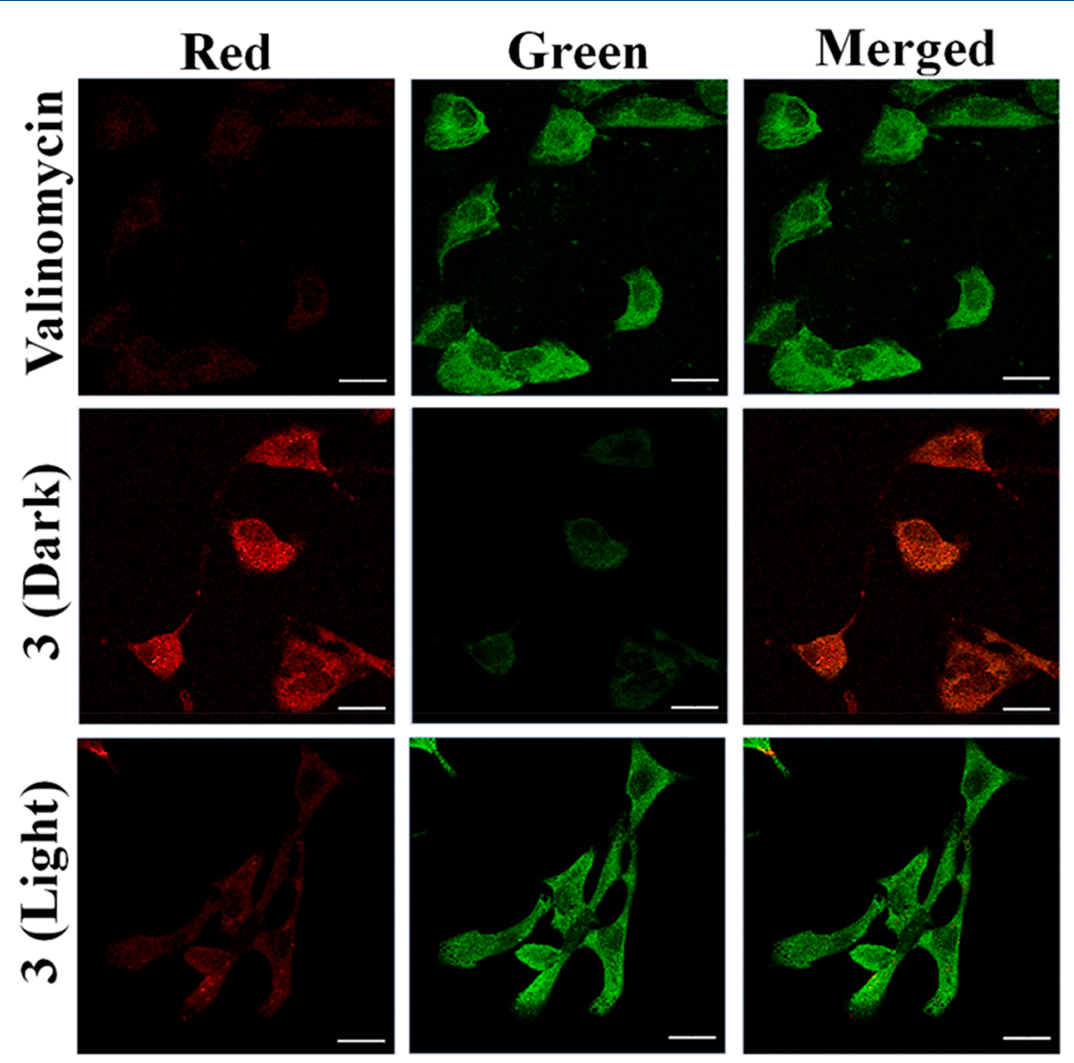

Figure 7. Confocal microscopic images from JC-1 assay showing the fluorescence images of JC-1 dye in both red and green channel in A549 lung cancer cells incubated with the PDT active complex $3(5 \mu \mathrm{M})$ for $4 \mathrm{~h}$ at $37^{\circ} \mathrm{C}$ in dark and on visible light irradiation $(\lambda=400-700 \mathrm{~nm}$, light dose $=10 \mathrm{~J} \mathrm{~cm}^{-2}$ ). The last column shows the merged images of green and red channel. Scale bar is $20 \mu \mathrm{m}$.

The mitochondrial membrane potential is inversely proportional to the health of the cell. A low $\Delta \Psi_{\mathrm{m}}$ is an indication of the healthy cells showing red fluorescence due to formation of J-aggregates. A high $\Delta \Psi_{\mathrm{m}}$ leads to the formation of the monomer of JC-1 dye in cells leading to caspase-mediated cell death. ROS generation causes mitochondrial dysfunction that leads to variation in $\Delta \Psi_{\mathrm{m}}$.
Complex 3 was chosen for this study based on its potent PDT activity in all the cells used, specifically in A549 cells along with valinomycin, a well-known mitochondrial depolarizing agent, as the positive control. After $4 \mathrm{~h}$ preincubation of complex 3 in A549 cells, the sample was exposed to visible light ( $1 \mathrm{~h}, \lambda=400-700 \mathrm{~nm}$ ), and a gradual decrease in red fluorescence intensity was observed with subsequent increase 
in the green signal of the JC-1 dye (Figure 7). Valinomycin as a positive control gave the expected green signal of the dye.

Mitochondrial platinum uptake measurements were made by inductively coupled plasma mass spectrometry (ICP-MS). Complexes 1-4 $(100 \mu \mathrm{M})$ were treated with A549 cells and incubated for $4 \mathrm{~h}$ in dark. The mitochondrial DNA (mtDNA) was purified and isolated by using an isolation kit. Agarose gel electrophoresis data indicated the confinement of mtDNA from the mitochondria of the A549 cells. The data, obtained as nanogram (ng) platinum per ng of mitochondria, are listed in Table 2. The substantial accumulation of platinum was observed using complexes 1-3 compared to control complex 4 implying the importance of BODIPY units for the mitochondria-targeted photodynamic therapy.

Apoptosis. Annexin-V-FITC/PI assay was carried out to determine the mode of cell death by flow cytometry. The green fluorescence of annexin V-FITC dye and red fluorescence of propidium iodide (PI) allowed us to examine the cellular apoptosis (early apoptosis- high annexin, low PI; late apoptosis- high annexin and high PI), viable cell (unstained, showing auto fluorescence), and necrosis (stained by PI). Complexes 2-4 $(0.1 \mu \mathrm{M}$ for 2 and 3 and $10 \mu \mathrm{M}$ for 4$)$ were first treated with A549 cells and preincubated in dark for $4 \mathrm{~h}$ and finally exposed to visible light irradiation ( $1 \mathrm{~h}$ exposure, $\lambda$ $=400-700 \mathrm{~nm}$ ). Assay was performed after $19 \mathrm{~h}$ of incubation to quantify the apoptotic cells by flow cytometry. The diiodinated BODIPY complex 3 on light exposure showed $\sim 90 \%$ apoptosis compared to the monoiodinated BODIPY complex $2(\sim 51 \%)$ as viewed in the lower right quadrant of Figure 8 (Figures S54, S55, Supporting Information). Complexes 2 and 3 treated cells resulted in minimal $(\sim 10 \%)$ early apoptotic cell population, which is in accordance with the control set of cells that were left untreated or for complex 4 treated cells in dark and light. A comparative study showed the higher activity of the diiodo complex of pyriplatin-B over its Imidazoplatin-B analogue for higher efficacy of intracellular ROS generation (Figure S56, Supporting Information).

The cell cycle progression was used to investigate the mode of cell death. To examine the effect of visible light irradiation, the DNA content of the A549 cells treated with the complexes 2-4 (concentration: $0.1 \mu \mathrm{M}, 1-3 ; 10 \mu \mathrm{M}, 4$ ) was measured using the PI dye. The statistical analysis of histogram showed an increase in the sub-G1 cell population of $\sim 51 \%$ for $3, \sim 39 \%$ for 2 , $\sim 26 \%$ for 1 , and $10 \%$ for 4 after $1 \mathrm{~h}$ of photoexposure $(400-700 \mathrm{~nm})$ as compared to those samples unexposed to light (Figure 8b, Figures S57, S58, Supporting Information).

Complex 4 due to its nontoxic nature showed similar behavior as that of the untreated controls. The cellular apoptosis and cell cycle arrest assay results suggest the photocytotoxic order: $3>\mathbf{2}>\mathbf{1} \gg \mathbf{4}$. This order matches well with the singlet oxygen generation efficacy of the complexes.

9-Ethylguanine Binding. The monofunctional platinum(II) complexes are known to form single covalent adduct with the nuclear DNA by the loss of the chloride ligand. ${ }^{5,36-38}$ The binding ability of the complexes 1-4 with a model nucleobase, namely, 6-amino-9-ethyl-2-hydroxypurine (9-ethylguanine, 9EtG), was studied by NMR and HRMS spectroscopy. The N7 atom of guanine is the binding position of the metal, and a downfield chemical shift of the $\mathrm{H} 8$ proton which is immediate next to the N7 atom is known to occur in the ${ }^{1} \mathrm{H}$ NMR spectrum. Addition of three molar equivalents of $9-\mathrm{EtG}$ to the complexes 1-4 in $\mathrm{D}_{2} \mathrm{O}$ : DMSO- $d_{6}$ resulted in the formation of
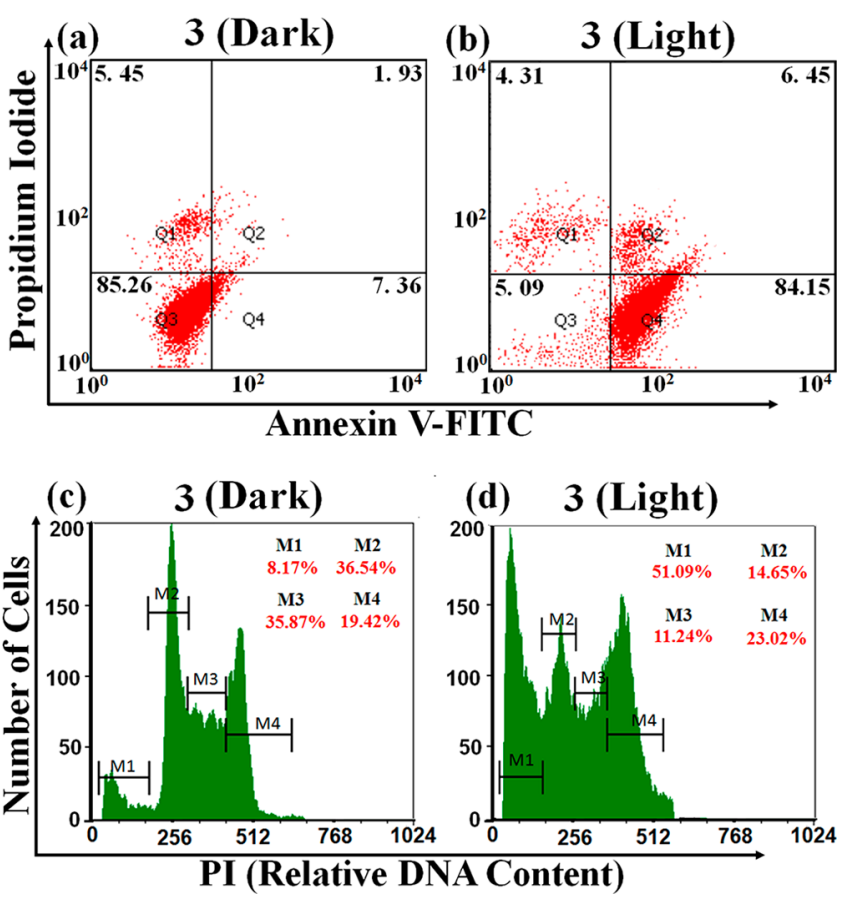

Figure 8. Dot plots obtained from the annexin V-FITC-PI assay using A549 lung cancer cells treated with the PDT active complex 3 and kept in the dark (a) or exposed to visible light $(400-700 \mathrm{~nm})(\mathrm{b})$. The respective \% cell population is given in the respective quadrants (lower left $=$ live cells, lower right $=$ early apoptotic cells, upper right $=$ late apoptotic/necrotic cells and upper left $=$ dead cells). Panel $(\mathrm{b})$ shows $\sim 84 \%$ early apoptotic cell population. Panels (c) and (d) show the histogram diagram representing \% cell population in different phases of cell cycle progression as denoted by M1-SubG1, M2-G1, M3-S, M4-G2/M indicated in the insets.

monoadducts as observed from the shift of the $\mathrm{H} 8$ proton signal of 9-EtG from 7.69 to $8.52 \mathrm{ppm}$ (marked as $\ddagger$ ) within 12 $\mathrm{h}$ and HRMS spectra (Scheme S1, Figures S59-S66, Supporting Information). Substitution of the chloride ligand could result in the formation of the monoadduct $\left[\mathrm{Pt}\left(\mathrm{NH}_{3}\right)_{2}\right.$ (L) $(9-E t G)]^{2+}(\mathrm{L}=$ pyridyl ligand $)$ as evidenced from the ${ }^{1} \mathrm{H}$ NMR spectral data and from the prominent HRMS peak along with the isotopic distribution at $308.1560 \mathrm{~m} / z$ value. The reaction seems to proceed with monoaquation with the substitution of the chloride ligand as the first step followed by ligation of 9-EtG to platinum(II). The presence of two additional signals at 8.44 and $8.46 \mathrm{ppm}$ in the ${ }^{1} \mathrm{H}$ NMR spectra in a 1:1 molar ratio suggests the possibility of both cis and trans adducts formation of $\left[\mathrm{Pt}\left(\mathrm{NH}_{3}\right)(\mathrm{L}) \mathrm{Cl}(9-\mathrm{EtG})\right]^{+}$with the loss of one ammine group of cis- $\left[\mathrm{Pt}\left(\mathrm{NH}_{3}\right)_{2}(\mathrm{~L}) \mathrm{Cl}\right]^{+}$instead of the chloride due to greater trans effect of chloride than the ammine group in the noncellular medium. ${ }^{8 b, 36}$ Besides these, another peak was observed at $8.56 \mathrm{ppm}$ which could possibly be due to the 9-EtG chelated adduct with the Pt(II) center with the loss of chloride and ammine ligands. This rather unusual chelation could occur through the $\mathrm{N}^{7}$ and $\mathrm{O}^{6}$ atoms of 9-EtG by displacing the ammine group of the pyriplatin core with the bidentate monoanionic 9-EtG giving a mass peak with $\mathrm{m} / \mathrm{z}$ value of 715.2740 assignable to $\left[\mathrm{Pt}^{\mathrm{II}}\left(\mathrm{NH}_{3}\right)(\mathrm{L})(9-\mathrm{EtG})\right]^{+}$with characteristic isotopic distribution (Scheme S1, Figures S59S66, Supporting Information). ${ }^{8 \mathrm{~b}}$ A similar speciation of the related platinum complexes was observed in our earlier study and also reported in the literature. ${ }^{8 b, 36-38}$ A new peak at 8.25 ppm suggested the formation of the hydrolyzed intermediate 
species (Scheme S1, Figures S59-S66, Supporting Information). The mechanistic data reveal the DNA cross-linking potential of the complexes, and this property could enhance their overall cytotoxicity when compared to that of the free ligands, thus highlighting the important role of platinum.

Photocleavage of Plasmid DNA. As the complexes showed predominant localization at the mitochondria $(\mathrm{mt})$, the mtDNA could be a possible target for binding of these complexes. The ability of the Pt-BODIPY conjugates to damage DNA upon photo exposure was studied by gel electrophoresis using supercoiled (SC) pUC19 DNA in Tris$\mathrm{HCl}$ buffer $(\mathrm{pH}=7.2)$ and a monochromatic visible light of $532 \mathrm{~nm}$ using a CW (continuous wave) diode laser of $100 \mathrm{~mW}$ (Figure S67, Supporting Information). The samples were treated with the SC DNA in Tris- $\mathrm{HCl}$ buffer and incubated in dark for $1 \mathrm{~h}$ and finally exposed to light for $1 \mathrm{~h}$. The complexes $(20 \mu \mathrm{M})$ did not show any significant DNA cleavage activity in the dark ( $\sim 7 \% \mathrm{NC})$. However, the BODIPY complexes showed formation of a significant quantity of nicked circular (NC) DNA in the presence of light giving an order: $3>\mathbf{2}>\mathbf{1}$ $\gg 4$ (Figure S67, Supporting Information).

To ascertain the nature of ROS, complexes 1-4 (20 $\mu \mathrm{M})$ were treated with the pUC19 DNA and photoexposed in the presence of different singlet oxygen quenchers, hydroxyl radical scavengers, and SOD as superoxide radical scavenger. The observed DNA photocleavage activity is in agreement with the singlet oxygen generation ability of the complexes with the diiodo-BODY complex being the most active, followed by the monoiodo and noniodo BODIPY complexes. Complex 3 in $\mathrm{D}_{2} \mathrm{O}$ showed enhancement in the DNA cleavage activity as singlet oxygen has longer lifetime in this solvent than in water. The photocleavage activity in the presence of $\mathrm{NaN}_{3}$ and 2,2,6,6-tetra-methylpiperidine (TEMP) as singlet oxygen quenchers got significantly reduced. Radical scavengers like KI, DMSO, and SOD (superoxide dismutase) did not show any apparent inhibitory effect. The mechanistic data unequivocally established the formation of singlet oxygen as the only ROS for these BODIPY complexes. Complex 4 (20 $\mu \mathrm{M})$ being photoinactive did not show any apparent DNA cleavage in both light and dark.

\section{CONCLUSIONS}

Pyriplatin derivatives of formulation cis- $\left[\mathrm{Pt}\left(\mathrm{NH}_{3}\right)_{2}(\mathrm{~L}) \mathrm{Cl}\right]$ $\left(\mathrm{NO}_{3}\right)$ of the $\mathrm{N}$-donor pyridyl ligand $(\mathrm{L})$ having pendant highly fluorescent BODIPY (in $\mathrm{L}^{1}$ ), moderately fluorescent monoiodo-BODIPY (in $\mathrm{L}^{2}$ ), and nonfluorescent diiodoBODIPY (in $\mathrm{L}^{3}$ ) moieties were prepared and characterized as new monofunctional platinum(II)-based PDT agents. The fluorescent properties of the complexes $\mathbf{1}$ and $\mathbf{2}$ with an emissive $L^{1}$ and $L^{2}$ were used for cellular imaging study which showed their predominant mitochondrial localization as evidenced from the high Pearson's coefficient value. Designing complexes targeting mitochondria is of importance as this allows one to circumvent the drawbacks associated with the nuclear DNA binding bifunctional platinum(II) drugs. Complex 3 having a BODIPY moiety with two iodine atoms in $\mathrm{L}^{3}$ is an efficient photosensitizer, and the complex showed PDT activity in visible light with $\mathrm{IC}_{50}$ values in nanomolar concentrations in different cells, while being essentially nontoxic in the dark. This highlights the utility of this class of platinum-based photosensitizers, named as "pyriplatin-B" (B stands for BODIPY), as potential substitutes for the organic macrocyclic PDT dyes, namely, photofrin and its porphyrin and phthalocyanine analogues. The ROS involved in the PDT activity is singlet oxygen $\left({ }^{1} \mathrm{O}_{2}\right)$ with $\Phi_{\Delta}$ values in the order: $3>$ $2>1$. While complex $\mathbf{1}$ is primarily suitable for the cellular imaging study with its high $\Phi_{\mathrm{F}}$ value, complex 3 is a potential PDT agent with a high $\Phi_{\Delta}$ value. Interestingly, complex 2 with a monoiodo-BODY core fits in-between making the complex suitable for both cellular imaging and PDT activity with moderate $\Phi_{\mathrm{F}}$ and $\Phi_{\Delta}$ values. The mechanistic noncellular study established the formation of different Pt-DNA adducts involving the complexes and 9-ethylguanine (9-EtG) as a model substrate. The mechanistic pathway involves multiple adduct formation with a replacement of chloride along with the substitution of an ammine base instead of the chloride due to a higher trans-effect of the chloride than the ammine base. Further in-depth biological studies are needed to understand the probable reaction pathway(s) within the cells. This work, in summary, provides new insights and directions in the chemistry of monofunctional platinum(II) complexes. The complexes as photoanalogues of pyriplatin with excellent anticancer activity on light activation akin to PDT effect of hematoporphyrin could act as potential substitutes of the macrocyclic organic dyes in photodynamic therapy applications.

\section{ASSOCIATED CONTENT}

\section{S Supporting Information}

The Supporting Information is available free of charge on the ACS Publications website at DOI: 10.1021/acs.inorgchem.8b02546.

Additional details of the experimental methods and measurements, NMR (Figures S1-S20), HPLC (Figure S21), HRMS (Figures S22-S28), IR spectra (Figures S29-S32), unit cell packing diagram of complex 4 and $\mathrm{L}^{1}-\mathrm{L}^{3}$ (Figures S33-S39), optimized structure and frontier molecular orbitals (Figure S40), UV-visible data (Figure S41), singlet oxygen generation (Figures S42, S43), DCFDA (Figures S44, S45), MTT assay (Figures S46-S52), confocal (Figure S53), FACS analysis (Figures S54-S58), DNA binding study with 9-EtG (Figures S59-S66), chemical nuclease, DNA photocleavage and mechanistic aspects (Figure S67), Scheme S1, crystallographic parameters and bond distances/angles (Tables S1-S3) and Cartesian coordinates of the complexes 1-3 (Table S4) (PDF)

\section{Accession Codes}

CCDC 1821177-1821180 contain the supplementary crystallographic data for this paper. These data can be obtained free of charge via www.ccdc.cam.ac.uk/data_request/cif, or by emailing data_request@ccdc.cam.ac.uk, or by contacting The Cambridge Crystallographic Data Centre, 12 Union Road, Cambridge CB2 1EZ, UK; fax: +44 1223336033.

\section{AUTHOR INFORMATION}

\section{Corresponding Authors}

*(P.K.) E-mail: paturu@iisc.ac.in. Tel.: +91-80-22932688. Fax: +91-80-23600999.

*(A.R.C.) e-mail: arc@iisc.ac.in. Tel.: +91-80-22932533. Fax: $+91-80-23600683$.

ORCID

Prodip Howlader: 0000-0001-6762-529X

Akhil R. Chakravarty: 0000-0002-6471-9167 


\section{Notes}

The authors declare no competing financial interest.

\section{ACKNOWLEDGMENTS}

The authors thank the Department of Science and Technology (DST), Government of India, for the financial support (SR/ S5/MBD-02/2007 and EMR/2015/000742). A.R.C. thanks the DST for J. C. Bose National Fellowship. P.K.'s research group is funded by DBT-IISc grants. M.K.R. thanks CSIR for his research fellowship. We thank Dr. Uttara, Urvashi, Sampratha, and Leepika for FACS data and Saima for the confocal microscopy images.

\section{REFERENCES}

(1) Cheff, D. M.; Hall, M. D. A Drug of Such Damned Nature.1 Challenges and Opportunities in Translational Platinum Drug Research. J. Med. Chem. 2017, 60, 4517-4532.

(2) Johnstone, T. C.; Suntharalingam, K.; Lippard, S. J. The Next Generation of Platinum Drugs: Targeted Pt(II) Agents, Nanoparticle Delivery, and Pt(IV) Prodrugs. Chem. Rev. 2016, 116, 3436-3486.

(3) (a) Farrell, N. P. Multi-Platinum Anti-Cancer Agents. Substitution-Inert Compounds for Tumor Selectivity and New Targets. Chem. Soc. Rev. 2015, 44, 8773-8785. (b) Wang, X.; Wang, X.; Guo, Z. Functionalization of Platinum Complexes for Biomedical Applications. Acc. Chem. Res. 2015, 48, 2622-2631.

(4) Wilson, J. J.; Lippard, S. J. Synthetic Methods for the Preparation of Platinum Anticancer Complexes. Chem. Rev. 2014, 114, 44704495.

(5) (a) Lovejoy, K. S.; Todd, R. C.; Zhang, S.; McCormick, M. S.; D’Aquino, J. A.; Reardon, J. T.; Sancar, A.; Giacomini, K. M.; Lippard, S. J. Cis-Diammine(pyridine)chloro-platinum(II), a Monofunctional platinum(II) Antitumor Agent: Uptake, Structure, Function, and Prospects. Proc. Natl. Acad. Sci. U. S. A. 2008, 105, 8902-8907. (b) Park, G. Y.; Wilson, J. J.; Song, Y.; Lippard, S. J. Phenanthriplatin, a Monofunctional DNA-Binding Platinum Anticancer Drug Candidate with Unusual Potency and Cellular Activity Profile. Proc. Natl. Acad. Sci. U. S. A. 2012, 109, 11987-11992.

(6) (a) Zhang, J.; Wang, X.; Tu, C.; Lin, J.; Ding, J.; Lin, L.; Wang, Z.; He, C.; Yan, C.; You, X.; Guo, Z. Monofunctional Platinum Complexes Showing Potent Cytotoxicity against Human Liver Carcinoma Cell Line BEL-7402. J. Med. Chem. 2003, 46, 35023507. (b) Brabec, V.; Hrabina, O.; Kasparkova, J. Cytotoxic Platinum Coordination Compounds. DNA Binding Agents. Coord. Chem. Rev. 2017, 351, 2-31.

(7) (a) Johnstone, T. C.; Wilson, J. J.; Lippard, S. J. Monofunctional and Higher-Valent Platinum Anticancer Agents. Inorg. Chem. 2013, 52, 12234-12249. (b) Weidmann, A. G.; Barton, J. K. A Monofunctional Platinum Complex Coordinated to a Rhodium Metalloinsertor Selectively Binds Mismatched DNA in the Minor Groove. Inorg. Chem. 2015, 54, 9626-9636.

(8) (a) Xue, X.; Zhu, C.; Chen, H.; Bai, Y.; Shi, X.; Jiao, Y.; Chen, Z.; Miao, Y.; He, W.; Guo, Z. A New Approach to Sensitize Antitumor Monofunctional Platinum(II) Complexes via Short Time Photo-Irradiation. Inorg. Chem. 2017, 56, 3754-3762. (b) Raza, M. K.; Gautam, S.; Garai, A.; Mitra, K.; Kondaiah, P.; Chakravarty, A. R. Monofunctional BODIPY-Appended Imidazoplatin for Cellular Imaging and Mitochondria-Targeted Photocytotoxicity. Inorg. Chem. 2017, 56, 11019-11029. (c) Ramu, V.; Gautam, S.; Garai, A.; Kondaiah, P.; Chakravarty, A. R. Glucose-Appended Platinum(II)BODIPY Conjugates for Targeted Photodynamic Therapy in Red Light. Inorg. Chem. 2018, 57, 1717-1726.

(9) Zhu, G.; Myint, M.; Ang, W. H.; Song, L.; Lippard, S. J. Monofunctional Platinum-DNA Adducts Are Strong Inhibitors of Transcription and Substrates for Nucleotide Excision Repair in Live Mammalian Cells. Cancer Res. 2012, 72, 790-800.

(10) (a) Alexeyev, M.; Shokolenko, I.; Wilson, G.; LeDoux, S. The Maintenance of Mitochondrial DNA Integrity-Critical Analysis and
Update. Cold Spring Harbor Perspect. Biol. 2013, 5, a012641a012641. (b) Cline, S. D. Mitochondrial DNA Damage and Its Consequences for Mitochondrial Gene Expression. Biochim. Biophys. Acta, Gene Regul. Mech. 2012, 1819, 979-991.

(11) Chakrabortty, S.; Agrawalla, B. K.; Stumper, A.; Vegi, N. M.; Fischer, S.; Reichardt, C.; Kögler, M.; Dietzek, B.; Feuring-Buske, M.; Buske, C.; Rau, S.; Weil, T. Mitochondria Targeted ProteinRuthenium Photosensitizer for Efficient Photodynamic Applications. J. Am. Chem. Soc. 2017, 139, 2512-2519.

(12) (a) Li, X.; Zheng, B.-D.; Peng, X.-H.; Li, S.-Z.; Ying, J.-W.; Zhao, Y.; Huang, J.-D.; Yoon, J. Phthalocyanines as Medicinal Photosensitizers: Developments in the Last Five Years. Coord. Chem. Rev. 2017, DOI: 10.1016/j.ccr.2017.08.003. (b) Wen, R.; Banik, B.; Pathak, R. K.; Kumar, A.; Kolishetti, N.; Dhar, S. Nanotechnology Inspired Tools for Mitochondrial Dysfunction Related Diseases. Adv. Drug Delivery Rev. 2016, 99, 52-69. (c) Laws, K.; Bineva-Todd, G.; Eskandari, A.; Lu, C.; O’Reilly, N.; Suntharalingam, K. A. Copper(II) Phenanthroline Metallopeptide That Targets and Disrupts Mitochondrial Function in Breast Cancer Stem Cells. Angew. Chemie - Int. Ed. 2018, 57, 287-291, DOI: 10.1002/anie.201710910.

(13) (a) Cao, J.-J.; Tan, C.-P.; Chen, M.-H.; Wu, N.; Yao, D.-Y.; Liu, X.-G.; Ji, L.-N.; Mao, Z.-W. Targeting Cancer Cell Metabolism with Mitochondria-Immobilized Phosphorescent Cyclometalated Iridium(III) Complexes. Chem. Sci. 2017, 8, 631-640. (b) Venkatesh, V.; Berrocal-Martin, R.; Wedge, C. J.; Romero-Canelón, I.; SanchezCano, C.; Song, J.-I.; Coverdale, J. P. C.; Zhang, P.; Clarkson, G. J.; Habtemariam, A.; Magennis, S. W.; Deeth, R. J.; Sadler, P. J. Mitochondria-Targeted Spin-Labelled Luminescent Iridium Anticancer Complexes. Chem. Sci. 2017, 8, 8271-8278.

(14) (a) Bhattacharyya, A.; Dixit, A.; Mitra, K.; Banerjee, S.; Karande, A. A.; Chakravarty, A. R. BODIPY Appended Copper(II) Complexes of Curcumin Showing Mitochondria Targeted Remarkable Photocytotoxicity in Visible Light. MedChemComm 2015, 6, 846-851. (b) Zhang, X.; Ai, F.; Sun, T.; Wang, F.; Zhu, G. Multimodal Upconversion Nanoplatform with a MitochondriaTargeted Property for Improved Photodynamic Therapy of Cancer Cells. Inorg. Chem. 2016, 55, 3872-3880.

(15) (a) Loudet, A.; Burgess, K. BODIPY Dyes and Their Derivatives: Syntheses and Spectroscopic Properties. Chem. Rev. 2007, 107, 4891-4932. (b) Ulrich, G.; Ziessel, R.; Harriman, A. The Chemistry of Fluorescent Bodipy Dyes: Versatility Unsurpassed. Angew. Chem., Int. Ed. 2008, 47, 1184-1201.

(16) Kamkaew, A.; Lim, S. H.; Lee, H. B.; Kiew, L. V.; Chung, L. Y.; Burgess, K. BODIPY Dyes in Photodynamic Therapy. Chem. Soc. Rev. 2013, 42, 77-88.

(17) (a) Lincoln, R.; Greene, L. E.; Zhang, W.; Louisia, S.; Cosa, G. Mitochondria Alkylation and Cellular Trafficking Mapped with a Lipophilic BODIPY-Acrolein Fluorogenic Probe. J. Am. Chem. Soc. 2017, 139, 16273-16281. (b) Turksoy, A.; Yildiz, D.; Akkaya, E. U. Photosensitization and Controlled Photosensitization with BODIPY Dyes. Coord. Chem. Rev. 2017, DOI: 10.1016/j.ccr.2017.09.029.

(18) Gorman, A.; Killoran, J.; O’Shea, C.; Kenna, T.; Gallagher, W. M.; O'Shea, D. F. In Vitro Demonstration of the Heavy-Atom Effect for Photodynamic Therapy. J. Am. Chem. Soc. 2004, 126, 1061910631.

(19) Qiu, K.; Chen, Y.; Rees, T. W.; Ji, L.; Chao, H. OrganelleTargeting Metal Complexes: From Molecular Design to BioApplications. Coord. Chem. Rev. 2017, DOI: 10.1016/ j.ccr.2017.10.022.

(20) (a) Miller, M. A.; Askevold, B.; Yang, K. S.; Kohler, R. H.; Weissleder, R. Platinum Compounds for High-Resolution in Vivo Cancer Imaging. ChemMedChem 2014, 9, 1131-1135. (b) Miller, M. A.; Zheng, Y. R.; Gadde, S.; Pfirschke, C.; Zope, H.; Engblom, C.; Kohler, R. H.; Iwamoto, Y.; Yang, K. S.; Askevold, B.; Kolishetti, N.; Pittet, M.; Lippard, S. J.; Farokhzad, O. C.; Weissleder, R. TumourAssociated Macrophages Act as a Slow-Release Reservoir of NanoTherapeutic Pt(IV) pro-Drug. Nat. Commun. 2015, 6, 1-13.

(21) (a) Sun, T.; Guan, X.; Zheng, M.; Jing, X.; Xie, Z. Mitochondria-Localized Fluorescent BODIPY-Platinum Conjugate. 
ACS Med. Chem. Lett. 2015, 6, 430-433. (b) Liu, Y.; Li, Z.; Chen, L.; Xie, Z. Near Infrared BODIPY-Platinum Conjugates for Imaging, Photodynamic Therapy and Chemotherapy. Dyes Pigm. 2017, 141, 512.

(22) (a) Zhu, Z.; Wang, X.; Li, T.; Aime, S.; Sadler, P. J.; Guo, Z. Platinum(II)-gadolinium(III) Complexes as Potential Single-Molecular Theranostic Agents for Cancer Treatment. Angew. Chem., Int. Ed. 2014, 53, 13225-13228. (b) Ethirajan, M.; Chen, Y.; Joshi, P.; Pandey, R. K. The Role of Porphyrin Chemistry in Tumor Imaging and Photodynamic Therapy. Chem. Soc. Rev. 2011, 40, 340-362.

(23) (a) Zhao, J.; Xu, K.; Yang, W.; Wang, Z.; Zhong, F. The Triplet Excited State of Bodipy: Formation, Modulation and Application. Chem. Soc. Rev. 2015, 44, 8904-8939. (b) Mitra, K.; Gautam, S.; Kondaiah, P.; Chakravarty, A. R. BODIPY-Appended 2-(2-Pyridyl)benzimidazole Platinum(II) Catecholates for Mitochondria-Targeted Photocytotoxicity. ChemMedChem 2016, 11, 1956-1967.

(24) (a) Knoll, J. D.; Albani, B. A.; Turro, C. New Ru(II) Complexes for Dual Photoreactivity: Ligand Exchange and ${ }^{1} \mathrm{O}_{2}$ Generation. Acc. Chem. Res. 2015, 48, 2280-2287. (b) Raza, M. K.; Mitra, K.; Shettar, A.; Basu, U.; Kondaiah, P.; Chakravarty, A. R. Photoactive platinum(II) $\beta$-Diketonates as Dual Action Anticancer Agents. Dalton Trans. 2016, 45, 13234-13243.

(25) (a) Castano, A. P.; Mroz, P.; Hamblin, M. R. Photodynamic Therapy and Anti-Tumour Immunity. Nat. Rev. Cancer 2006, 6, 535545. (b) Fan, W.; Huang, P.; Chen, X. Overcoming the Achilles' Heel of Photodynamic Therapy. Chem. Soc. Rev. 2016, 45, 6488-6519.

(26) Bartelmess, J.; Francis, A. J.; El Roz, K. A.; Castellano, F. N.; Weare, W. W.; Sommer, R. D. Light-Driven Hydrogen Evolution by BODIPY-Sensitized Cobaloxime Catalysts. Inorg. Chem. 2014, 53, 4527-4534.

(27) (a) Walker, N.; Stuart, D. An Empirical Method for Correcting Diffractometer Data for Absorption Effects. Acta Crystallogr., Sect. A: Found. Crystallogr. 1983, 39, 158-166. (b) Sheldrick, G. M. Crystal structure refinement with SHELXL. Acta Crystallogr., Sect. C: Struct. Chem. 2015, 71, 3-8. (c) Farrugia, L. WinGX and ORTEP for Windows: an update. J. Appl. Crystallogr. 2012, 45, 849-854.

(28) (a) Becke, A. D. Density-Functional Exchange-Energy Approximation with Correct Asymptotic Behavior. Phys. Rev. A: At., Mol., Opt. Phys. 1988, 38, 3098-3100. (b) Becke, A. D. DensityFunctional Thermochemistry. III. The Role of Exact Exchange. J. Chem. Phys. 1993, 98, 5648.

(29) Frisch, M. J.; Trucks, G. W.; Schlegel, H. B.; Scuseria, G. E.; Robb, M. A.; Cheeseman, J. R.; Montgomery, J. A., Jr.; Vreven, T.; Kudin, K. N.; Burant, J. C.; Millam, J. M.; Iyengar, S. S.; Tomasi, J.; Barone, V.; Mennucci, B.; Cossi, M.; Scalmani, G.; Rega, N.; Petersson, G. A.; Nakatsuji, H.; Hada, M.; Ehara, M.; Toyota, K.; Fukuda, R.; Hasegawa, J.; Ishida, M.; Nakajima, T.; Honda, Y.; Kitao, O.; Nakai, H.; Klene, M.; Li, X.; Knox, J. E.; Hratchian, H. P.; Cross, J. B.; Bakken, V.; Adamo, C.; Jaramillo, J.; Gomperts, R.; Stratmann, R. E.; Yazyev, O.; Austin, A. J.; Cammi, R.; Pomelli, C.; Ochterski, J. W.; Ayala, P. Y.; Morokuma, K.; Voth, G. A.; Salvador, P.; Dannenberg, J. J.; Zakrzewski, V. G.; Dapprich, S.; Daniels, A. D.; Strain, M. C.; Farkas, O.; Malick, D. K.; Rabuck, A. D.; Raghavachari, K.; Foresman, J. B.; Ortiz, J. V.; Cui, Q.; Baboul, A. G.; Clifford, S.; Cioslowski, J.; Stefanov, B. B.; Liu, G.; Liashenko, A.; Piskorz, P.; Komaromi, I.; Martin, R. L.; Fox, D. J.; Keith, T.; Al-Laham, M. A.; Peng, C. Y.; Nanayakkara, A.; Challacombe, M.; Gill, P. M. W.; Johnson, B.; Chen, W.; Wong, M. W.; Gonzalez, C.; Pople, J. A. Gaussian 03, revision B.4; Gaussian Inc.: Pittsburgh, PA, 2003.

(30) Boens, N.; Leen, V.; Dehaen, W.; Wang, L.; Robeyns, K.; Qin, W.; Tang, X.; Beljonne, D.; Tonnelé, C.; Paredes, J. M.; RuedasRama, M. J.; Orte, A.; Crovetto, L.; Talavera, E. M.; Alvarez-Pez, J. M. Visible Absorption and Fluorescence Spectroscopy of Conformationally Constrained, Annulated BODIPY Dyes. J. Phys. Chem. A 2012, 116, 9621-9631.

(31) Zou, J.; Yin, Z.; Ding, K.; Tang, Q.; Li, J.; Si, W.; Shao, J.; Zhang, Q.; Huang, W.; Dong, X. BODIPY Derivatives for Photodynamic Therapy: Influence of Configuration versus Heavy Atom Effect. ACS Appl. Mater. Interfaces 2017, 9, 32475-32481.
(32) De Simone, B. C.; Mazzone, G.; Pirillo, J.; Russo, N.; Sicilia, E. Halogen Atom Effect on the Photophysical Properties of Substituted Aza-BODIPY Derivatives. Phys. Chem. Chem. Phys. 2017, 19, 25302536.

(33) Redmond, R. W.; Gamlin, J. N. A Compilation of Singlet Oxygen Yields from Biologically Relevant Molecules. Photochem. Photobiol. 1999, 70, 391-475.

(34) Wang, H.; Joseph, J. A. Quantifying Cellular Oxidative Stress by Dichlorofluorescein Assay using Microplate Reader. Free Radical Biol. Med. 1999, 27, 612-616.

(35) Dabrowski, J. M.; Arnaut, L. G. Photodynamic Therapy (PDT) of Cancer: From Local to Systemic Treatment. Photochem. Photobiol. Sci. 2015, 14, 1765-1780.

(36) (a) Kellinger, M. W.; Park, G. Y.; Chong, J.; Lippard, S. J.; Wang, D. Effect of a Monofunctional Phenanthriplatin-DNA Adduct on RNA Polymerase II Transcriptional Fidelity and Translesion Synthesis. J. Am. Chem. Soc. 2013, 135, 13054-13061. (b) Riddell, I. A.; Johnstone, T. C.; Park, G. Y.; Lippard, S. J. Nucleotide Binding Preference of the Monofunctional Platinum Anticancer-Agent Phenanthriplatin. Chem. - Eur. J. 2016, 22, 7574-7581.

(37) (a) Reedijk, J. Fast and Slow versus Strong and Weak metalDNA Binding: Consequences for Anti-Cancer Activity. Metallomics 2012, 4, 628-632. (b) Ranasinghe, K.; Pakhomova, S.; Marzilli, P. A.; Marzilli, L. G. A Very Rare Example of a Structurally Characterized 3'-GMP Metal Complex. NMR and Synthetic Assessment of Adducts Formed by Guanine Derivatives with $\left[\mathrm{Pt}\left(\mathrm{L}^{\text {tri }}\right) \mathrm{Cl}\right] \mathrm{Cl}$ Complexes with an $\mathrm{N}, \mathrm{N}^{\prime}, \mathrm{N}^{\prime \prime}$ Tridentate Ligand $\left(\mathrm{L}^{\text {tri }}\right)$ Terminated by Imidazole Rings. Inorg. Chem. 2017, 56, 8462-8477.

(38) (a) Karmakar, S.; Purkait, K.; Chatterjee, S.; Mukherjee, A. Anticancer Activity of a Cis-Dichloridoplatinum(II) Complex of a Chelating Nitrogen Mustard: Insight into Unusual Guanine Binding Mode and Low Deactivation by Glutathione. Dalton Trans. 2016, 45, 3599-3615. (b) Müller, B.; Shen, W.-Z.; Sanz Miguel, P. J.; Albertí, F. M.; van der Wijst, T.; Noguera, M.; Rodríguez-Santiago, L.; Sodupe, M.; Lippert, B. PtII Coordination to N1 of 9-Methylguanine: Why It Facilitates Binding of Additional Metal Ions to the Purine Ring. Chem. - Eur. J. 2011, 17, 9970-9983. 